US Army Corps

of Engineers

Waterways Experiment

Station

\title{
Physical Model Study of Breakwater Stability, Kodiak, Alaska
}

by Donald L. Ward, Willie G. Dubose

Approved For Public Release; Distribution Is Unlimited 
The contents of this report are not to be used for advertising, publication, or promotional purposes. Citation of trade names does not constitute an official endorsement or approval of the use of such commercial products. 


\section{Physical Model Study of Breakwater Stability, Kodiak, Alaska}

by Donald L. Ward, Willie G. Dubose

U.S. Army Corps of Engineers

Watenways Experiment Station

3909 Halls Ferry Road

Vicksburg, MS 39180-6199

Final report

Approved for public release; distribution is unlimited 


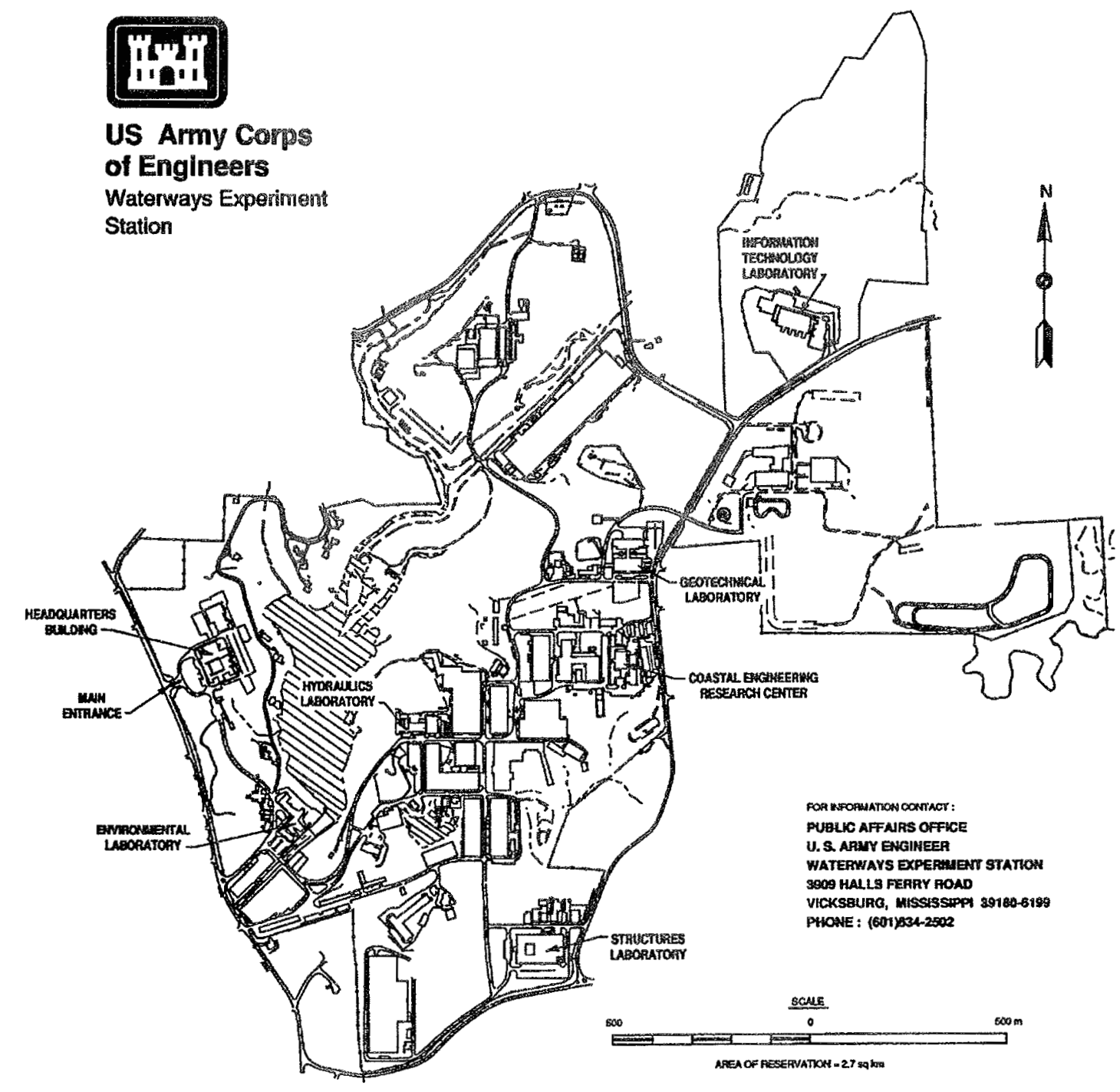

Waterways Experiment Station Cataloging-in-Publication Data

Ward, Donald L.

Physical model study of breakwater stability, Kodiak, Alaska / by Donald L.

Ward, Willie G. Dubose ; prepared for U.S. Army Engineer District, Alaska.

56 p. : ill. ; $28 \mathrm{~cm}$. - (Miscellaneous paper ; CERC-96-3)

Includes bibliographic references.

1. Breakwaters - Alaska - Kodiak. 2. Hydraulic models. 3. Breakwaters -

Stability. I. Dubose, Willie G. II. United States. Army. Corps of Engineers.

Alaska District. III. U.S. Army Engineer Watemays Experiment Station.

IV. Coastal Engineering Research Center (U.S. Army Engineer Waterways

Experiment Station) V. Title. VI. Series: Miscellaneous paper (U.S. Army

Engineer Waterways Experiment Station); CERC-96-3.

TA7 W34m no.CERC-96-3 


\section{Contents}

Preface $\ldots \ldots \ldots \ldots \ldots \ldots \ldots \ldots \ldots \ldots \ldots \ldots$

Conversion Factors, Non-SI to SI Units of Measurement $\ldots \ldots \ldots \ldots$ vi

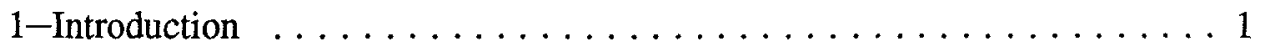

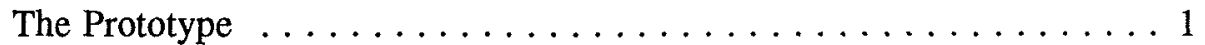

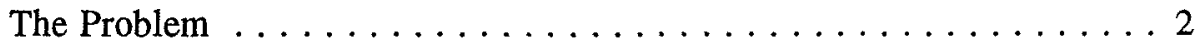

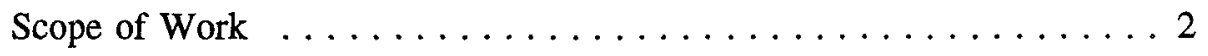

2-Test Facility $\ldots \ldots \ldots \ldots \ldots \ldots \ldots \ldots \ldots \ldots \ldots \ldots \ldots \ldots \ldots \ldots \ldots$

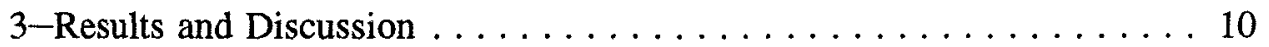

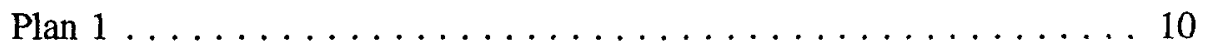

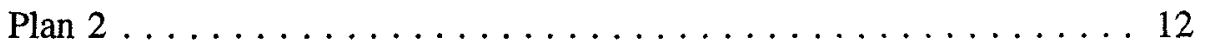

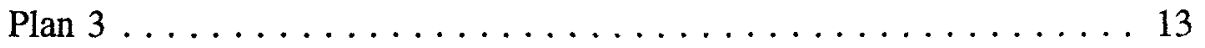

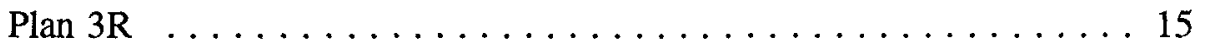

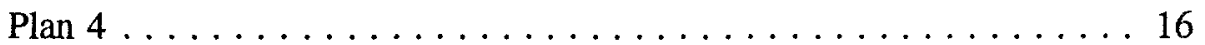

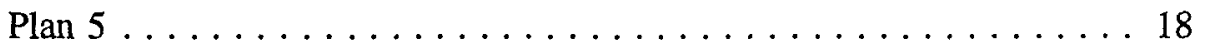

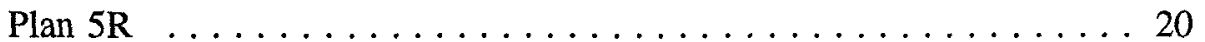

Conservatism .................... 21

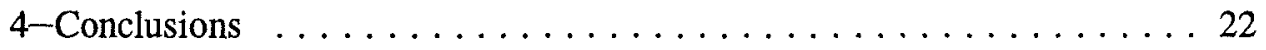

Photos 1-28

Appendix A: Notation . . . . . . . . . . . . . . . A1

SF 298

\section{List of Figures}

Figure 1 . Site location $\ldots \ldots \ldots \ldots \ldots \ldots \ldots \ldots$

Figure 2. Core-Loc concrete armor units $\ldots \ldots \ldots \ldots \ldots \ldots$ 
Figure 3. Overhead view of Plan 1 in test flume $\ldots \ldots \ldots \ldots$

Figure 4. Two-dimensional test flume $\ldots \ldots \ldots \ldots \ldots \ldots$

Figure 5. Cross section of breakwater trunk, Plan $1 \ldots \ldots \ldots \ldots$

Figure 6. Cross section of breakwater head, Plan $1 \ldots \ldots \ldots \ldots \ldots 11$

Figure 7. Cross section of breakwater trunk, Plan $3 \ldots \ldots \ldots 14$

Figure 8. Cross section, breakwater trunk, Plan $5 \ldots \ldots \ldots$

Figure 9. Cross section, breakwater head, Plan $5 \ldots \ldots \ldots$ 


\section{Preface}

This report presents results of a physical model study of the stability of the proposed main breakwater at St. Herman Harbor, Kodiak, AK. The work was authorized by a cooperative agreement between the U.S. Army Engineer Waterways Experiment Station (WES) and U.S. Army Engineer District, Alaska (NPA). Funds for the physical model study were approved by NPA in July and October, 1994.

Model testing was conducted at WES during the period June to November 1994 by personnel of the Coastal Engineering Research Center (CERC) under the direction of Dr. James R. Houston, Jr., Director, CERC, and Mr. Charles C. Calhoun, Assistant Director, CERC, and under the direct supervision of Messrs. C.E. Chatham, Jr., Chief, Wave Dynamics Division, and D.D. Davidson, Chief, Wave Research Branch. The models were constructed and tested by Mr. Willie G. Dubose, Civil Engineering Technician, under the supervision of Mr. Donald L. Ward, Principal Investigator. This report was prepared by Messrs. Ward and Dubose.

During the course of the investigation, liaison was maintained by means of conferences, telephone conversations, and monthly progress reports. Point of contact at NPA was Mr. Kenneth Eisses. Messrs. Eisses and Carl Stormer visited the model during operation.

Dr. Robert W. Whalin was Director of WES during model testing and the preparation and publication of this report. COL Leonard G. Hassell, EN, and COL Bruce K. Howard, EN, were Commanders. 


\section{Conversion Factors, Non-SI to SI Units of Measurement}

Non-SI units of measurement used in this report can be converted to SI units as follows:

\begin{tabular}{|l|l|l|}
\hline Multiply & By & To Obtain \\
\hline feet & 0.3048 & meters \\
\hline inches & 2.5400 & centimeters \\
\hline inches & 25.400 & millimeters \\
\hline pounds (mass) & 0.4535924 & kilograms \\
\hline pounds (mass) per cubic foot & 16.01846 & kilograms per cubic meter \\
\hline tons, short & 0.90718 & metric tonnes \\
\hline
\end{tabular}




\section{Introduction}

\section{The Prototype}

St. Herman Harbor is located south of the city of Kodiak, AK, and is bordered by Gull, Uski, and Near Islands (Figure 1). Kodiak is the third largest commercial fishing port in the United States, one of the four largest national producers of halibut, one of the world's top producers of king crab, and an important cargo port and transhipment center. The harbors at Kodiak (Kodiak Harbor, St. Herman Harbor, and Old Harbor) and Point Lions are the only protected basins between Cook Inlet and the Shumagin Islands, and therefore are important harbors of refuge.

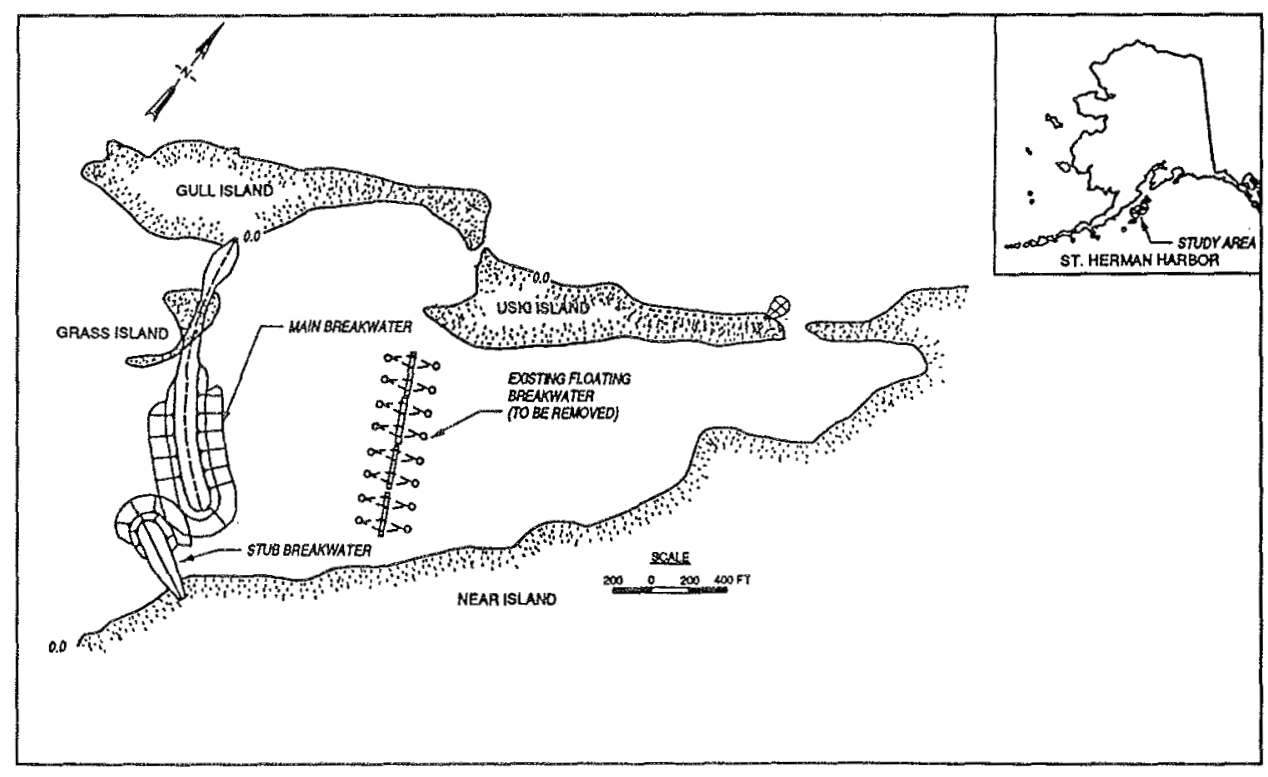

Figure 1. Site location

St. Herman Harbor is currently protected by a floating breakwater that does not provide adequate protection against incident wave conditions. A new main breakwater and stub breakwater, both of rubble-mound construction, are being built to supplement the floating breakwater and increase the level of protection. The U.S. Army Engineer District, Alaska (NPA) has determined that the most 
common wave incident upon the proposed rubble-mound breakwaters will have a height of $1.7 \mathrm{~m}(5.5 \mathrm{ft})^{1}$ and a period of $4.1 \mathrm{sec}$, and will approach normal to the main breakwater center line. However, part of the breakwater can be reached by an open-ocean wave with a height of $2.1 \mathrm{~m}(7.0 \mathrm{ft})$ and a period of $14 \mathrm{sec}$, approaching at an angle of approximately $30 \mathrm{deg}$ off normal to the main breakwater center line. The main breakwater was designed for the openocean wave using armor stone with a median stone weight of $1,450 \mathrm{~kg}$ $(3,200 \mathrm{lb})$ and a range of 1,130 to $1,810 \mathrm{~kg}(2,500$ to $4,000 \mathrm{lb})$.

The main breakwater is being constructed in water depths up to $-18.3 \mathrm{~m}$ $(-60 \mathrm{ft})$ mean lower low water (mllw) over unconsolidated silt. A consolidation pad with $1 \mathrm{~V}: 5 \mathrm{H}$ side slopes was completed in September 1993 to a depth of $-6.1 \mathrm{~m}(-20 \mathrm{ft}) \mathrm{mllw}$. Construction of the main breakwater is scheduled to begin in April 1995.

\section{The Problem}

Local quarries currently in operation at Kodiak are unable to produce armor stone of the required size in sufficient quantity for the breakwater. Armor stone may therefore need to be barged to the site from distant quarries, significantly increasing construction costs. A preliminary design and economic study conducted by NPA indicated the cost of breakwater construction could be reduced by $\$ 1.2$ million (from $\$ 4.6$ million to $\$ 3.4$ million) by armoring the main breakwater with Core-Loc concrete armor units (Figure 2), recently developed at the Coastal Engineering Research Center (CERC), instead of armor stone if the armor stone has to be barged from distant quarries. Although the Core-Loc armor units have performed well in laboratory tests, Core-Locs have not yet been tested on a prototype structure and have had minimal testing under three-dimensional (3-D) conditions of a breakwater head. It was therefore imperative that the proposed breakwater design using Core-Locs be tested before being let out for bids.

\section{Scope of Work}

Initial scope of work for the physical model testing of the main breakwater at St. Herman Harbor was determined during a meeting held at CERC in June 1994. The following personnel were present at the meeting:
Mr. Kenneth Eisses
CENPA-EN-CW-HH
Mr. D. D. Davidson
C/CEWES-CW-R
Mr. Donald Ward
CEWES-CW-R

\footnotetext{
${ }^{1}$ Units of measurement in the text of this report are shown in SI (metric) units, followed by non-SI (British) units in parentheses. In addition, a table of factors for converting non-SI units of measurement used in plates, figures, photos, and tables to SI units is presented on page vi.
} 


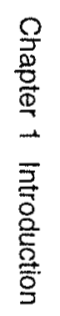

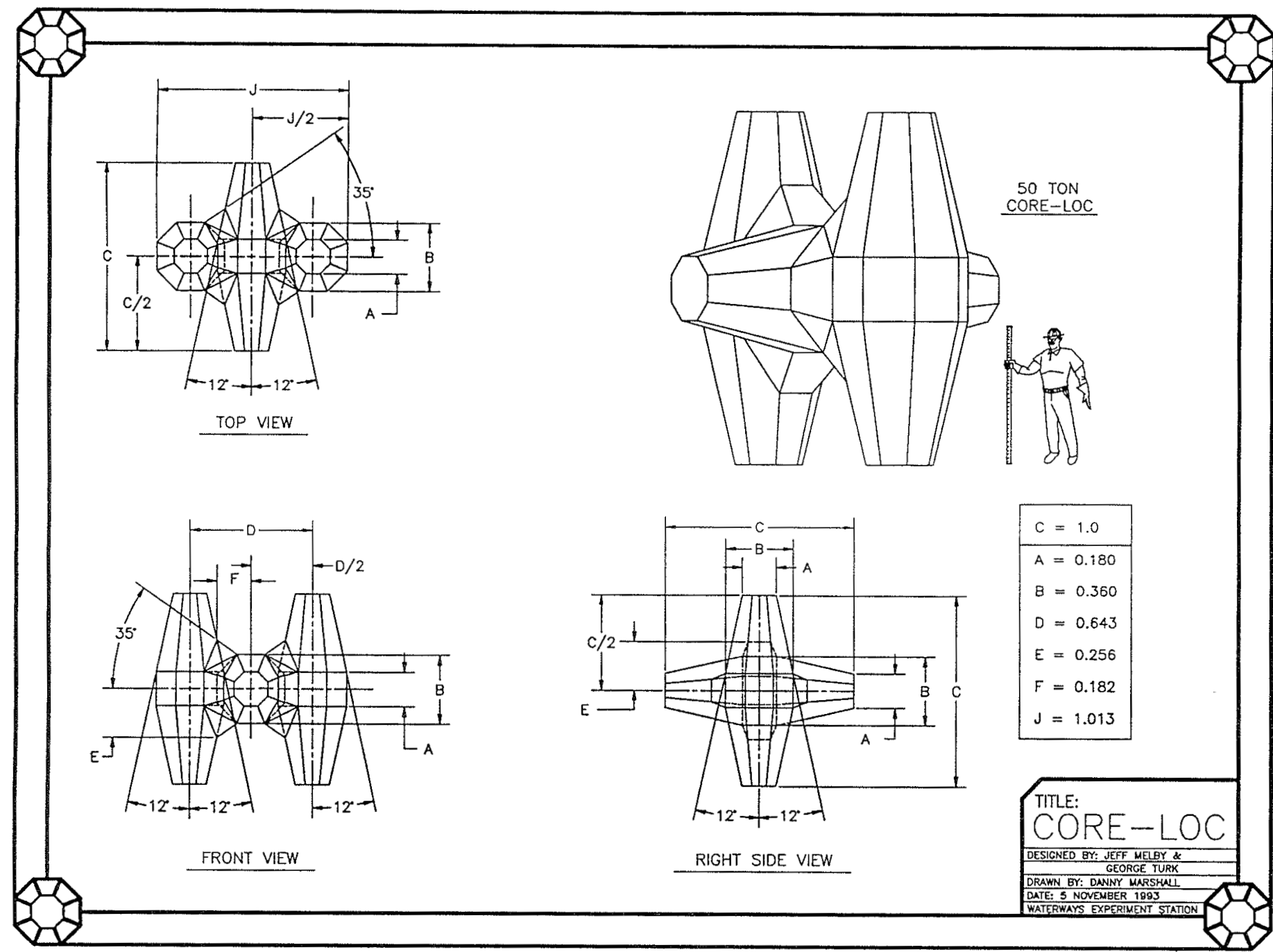

Figure 2. Core-Loc concrete armor units 


\section{Mr. Willie Dubose \\ Mr. Jeff Melby \\ Mr. George Turk \\ Mr. Robert Carver}

\author{
CEWES-CW-R \\ CEWES-CW-R \\ CEWES-CW-R \\ CEWES-CW-R
}

Primary concern of the model tests was stability of the structure head. Due to refraction, angle of incidence, and other 3-D effects, structure head tests are normally conducted in a 3-D wave basin. However, there were no 3-D wave basins available at CERC during the time frame in which the physical model tests were required. It was therefore decided to construct the model head extending out from one wall of one of the largest two-dimensional (2-D) wave flumes at CERC. The model would extend part-way across the flume, perpendicular to the flume walls, allowing wave action to be channeled past the model head. Because the stub breakwater at the prototype also will channel wave action past the main breakwater head, the "quasi-3-D" representation in the 2-D wave flume was thought to be adequate. The model would include the main breakwater head plus part of the breakwater trunk. Figure 3 illustrates the quasi-3-D nature of the test with an overhead view of Plan 1 in the test flume.

Preliminary analysis conducted at NPA indicated a 500-kg (1,100-1b) CoreLoc would be hydraulically stable under incident conditions of the open-ocean

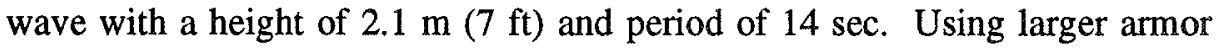
units would result in higher concrete costs but lower placement costs due to fewer units being required, with 1,350-kg (3,000-lb) Core-Locs providing the lowest total cost. Model tests were therefore conducted using scaled model units representing $1,350-\mathrm{kg}(3,000-\mathrm{lb})$ prototype units.

In order to construct the model breakwater head section at the largest practical scale, it was necessary to construct the model in a shallower depth than at the prototype. A consolidation pad on the prototype rises to an elevation of $-6.1 \mathrm{~m}(-20 \mathrm{ft}) \mathrm{mllw}$ from a depth of $-18.3 \mathrm{~m}(-60 \mathrm{ft}) \mathrm{mllw}$; the physical model reproduced only that portion of the consolidation pad from $-9.1 \mathrm{~m}$ $(-30 \mathrm{ft}) \mathrm{mllw}$ to $-6.1 \mathrm{~m}(-20 \mathrm{ft}) \mathrm{mllw}$.

Test conditions included high-water tests at a still-water level (swl) of $+3.20 \mathrm{~m}(10.5 \mathrm{ft}) \mathrm{mllw}$ to test structural stability and low-water tests at an swl of $0.0 \mathrm{~m}(0.0 \mathrm{ft}) \mathrm{mllw}$ to test toe stability and scour potential. Wave heights and periods included a wave height of $1.68 \mathrm{~m}(5.5 \mathrm{ft})$ with a $4.1-\mathrm{sec}$ wave period (determined by NPA to be the most common wave condition at the

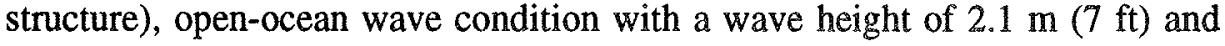
14-sec wave period, plus several intermediate test conditions.

Based on observations of response of the physical model to incident wave conditions, modifications to the scope of work were proposed during a meeting held at CERC in September 1994. The following personnel were present at the meeting: 


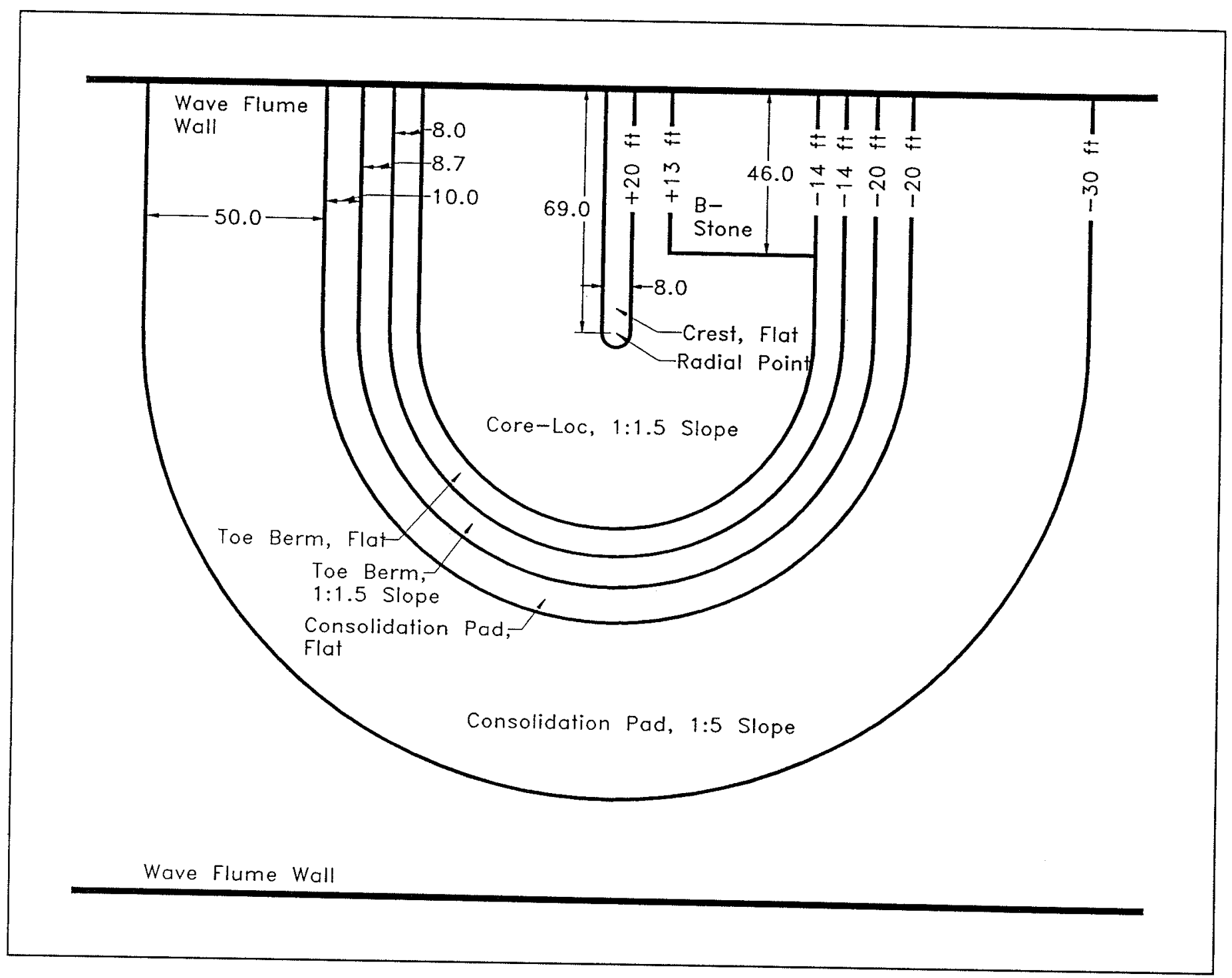

Figure 3. Overhead view of Plan 1 in test flume 


$\begin{array}{ll}\text { Mr. Kenneth Eisses } & \text { CENPA-EN-CW-HH } \\ \text { Mr. Carl Stormer } & \text { CENPA-EN-CW-PF } \\ \text { Mr. D. D. Davidson } & \text { C/CEWES-CW-R } \\ \text { Mr. Donald Ward } & \text { CEWES-CW-R } \\ \text { Mr. Willie Dubose } & \text { CEWES-CW-R } \\ \text { Mr. Jeff Melby } & \text { CEWES-CW-R } \\ \text { Mr. George Turk } & \text { CEWES-CW-R }\end{array}$

Changes to the scope of work included testing at additional swl's of $2.59 \mathrm{~m}$ $(8.5 \mathrm{ft}) \mathrm{mllw}$ and $3.81 \mathrm{~m}(12.5 \mathrm{ft}) \mathrm{mllw}$, and a limited test series using stone armor units instead of Core-Locs. 


\section{Test Facility}

Physical model stability studies were conducted by CERC's Wave Research Branch in wave flumes located at the U.S. Army Engineer Waterways Experiment Station (WES) in Vicksburg, MS. Descriptions of models, test conditions, and test results are given in prototype values unless stated otherwise; flume dimensions are given as actual dimensions of the facility. Tests were conducted at a scale of 1:23 (model:prototype).

Physical model tests were conducted in a $64-\mathrm{m}$-long (210-ft-long) by 3.0-m-wide (10-ft-wide) wave flume (Figure 4). The flume includes a 36-m-long (118.3-ft-long) by 1.5-m-deep (5-ft-deep) test section, then slopes at $1 \mathrm{~V}: 44.4 \mathrm{H}$ to a depth of $2.0 \mathrm{~m}(6.5 \mathrm{ft})$ at the wave generator. Waves were generated by a piston-type wave board powered by an electro-hydraulic pump controlled by a computer-generated signal. Capacitance-type wave gauges were placed in a three-gauge array in front of the wave board to record the generated wave train, with another three-gauge array located in front of the test structure to record wave trains near the structure. Three-gauge arrays were

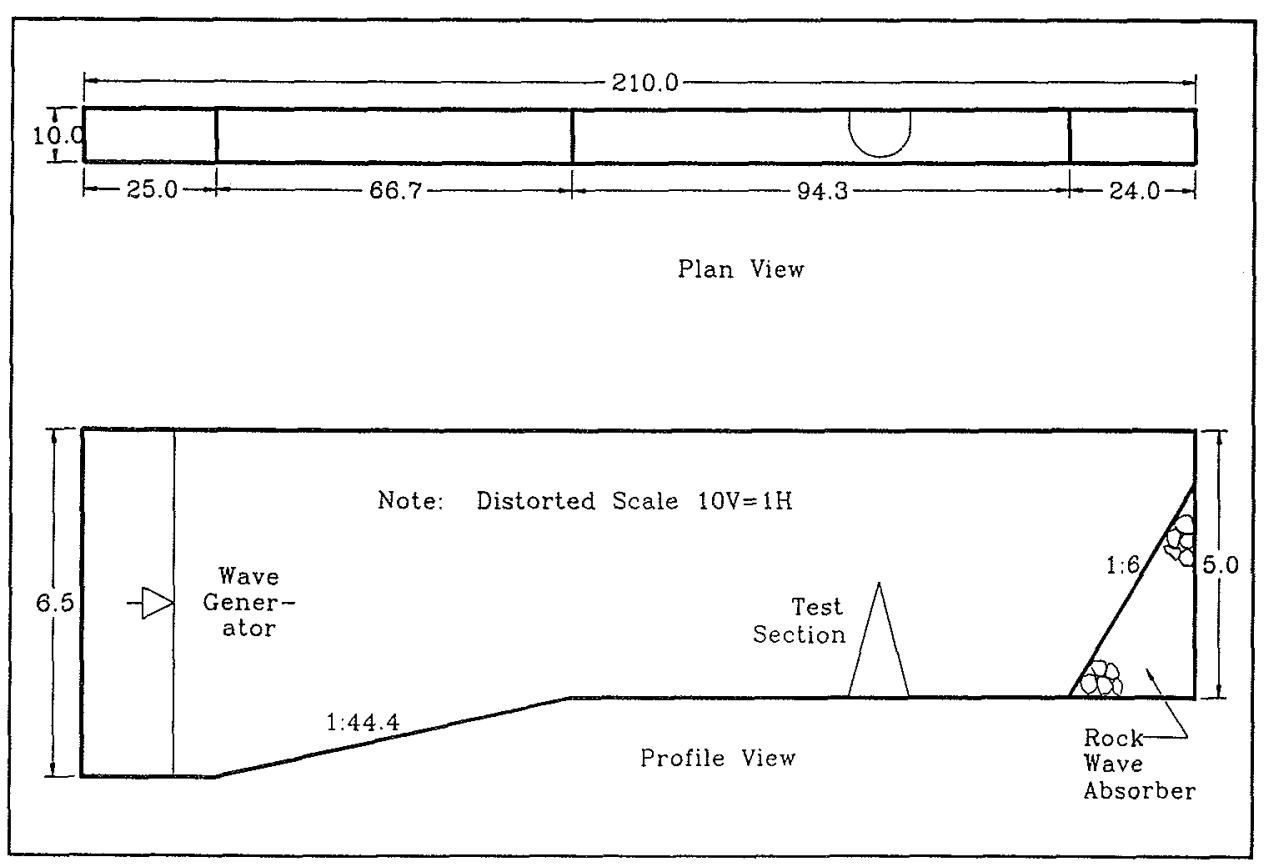

Figure 4. Two-dimensional test flume 
used to permit separation of incident and reflected wave trains by the method

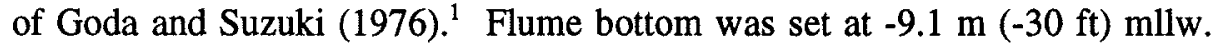
Bathymetry was not molded into the flume.

Based on Froude's model law (Stevens et al. 1942) ${ }^{2}$ and a scale of 1:23, the following model to prototype relationships were derived. Dimensions are in terms of length $L$ and time $T$.

\begin{tabular}{||l|l|l|l||}
\hline \hline Characteristic & Dimension & \multicolumn{2}{|l|}{ Model-to-Prototype Scale Relation } \\
\hline \hline Length & $\mathrm{L}$ & $\mathrm{L}_{\mathrm{r}}$ & $1: 23$ \\
\hline Area & $\mathrm{L}^{2}$ & $\mathrm{~A}_{\mathrm{r}}=\left(\mathrm{L}_{\mathrm{r}}\right)^{2}$ & $1: 529$ \\
\hline Volume & $\mathrm{L}^{3}$ & $\mathrm{~V}_{\mathrm{r}}=\left(\mathrm{L}_{\mathrm{r}}\right)^{3}$ & $1: 12,167$ \\
\hline Time & $\mathrm{T}$ & $\mathrm{T}_{\mathrm{r}}=\left(\mathrm{L}_{\mathrm{r}}\right)^{1 / 2}$ & $1: 4.80$ \\
\hline
\end{tabular}

To determine scaled weight of stone and concrete armor units to use in the model, the following transference equation was used:

$$
\frac{\left(W_{a}\right)_{m}}{\left(W_{a}\right)_{p}}=\frac{\left(\gamma_{a}\right)_{m}}{\left(\gamma_{a}\right)_{p}}\left(\frac{L_{m}}{L_{p}}\right)^{3}\left[\frac{\left(S_{a}\right)_{p}-1}{\left(S_{a}\right)_{m}-1}\right]^{3}
$$

where subscripts $m$ and $p$ refer to model and prototype values, respectively, and

$W_{a}=$ weight of an individual stone or armor unit, $\mathrm{lb}(\mathrm{N})$

$\gamma_{a}=$ specific weight of an individual stone or armor unit, $\mathrm{N} / \mathrm{m}^{3}\left(\mathrm{lb} / \mathrm{ft}^{3}\right)$

$L_{m} / L_{p}=$ linear scale of the model

$S_{a}=$ specific gravity of an individual stone or armor unit relative to the water in which the breakwater is constructed, i.e., $S_{a}=\gamma_{a} / \gamma_{w}$ where $\gamma_{w}=$ specific weight of water, $\mathrm{N} / \mathrm{m}^{3}\left(\mathrm{lb} / \mathrm{ft}^{3}\right)$

Stone selection for the model tests assumed a unit weight of $2,640 \mathrm{~kg} / \mathrm{m}^{3}$ $\left(165 \mathrm{lb} / \mathrm{ft}^{3}\right)$ for rock on both model and prototype, $1,025 \mathrm{~kg} / \mathrm{m}^{3}\left(64.0 \mathrm{lb} / \mathrm{ft}^{3}\right)$ for water at the prototype and $1,000 \mathrm{~kg} / \mathrm{m}^{3}\left(62.4 \mathrm{lb} / \mathrm{ft}^{3}\right)$ for water in the model. Concrete armor units were scaled assuming $2,320 \mathrm{~kg} / \mathrm{m}^{3}\left(145 \mathrm{lb} / \mathrm{ft}^{3}\right)$ for proto-

\footnotetext{
${ }^{1}$ Goda, T., and Suzuki, Y. (1976). "Estimation of incident and reflected waves in random wave experiments." Proceedings of the 15th Coastal Engineering Conference. Honolulu, HI, 828-845.

${ }^{2}$ Stevens, J.C., Bardsley, C.E., Lane, E.W., and Straub, L.G. (1942). "Hydraulic models," Manuals on Engineering Practice No. 25, American Society of Civil Engineers, New York.
} 
type concrete armor units, and $2,280 \mathrm{~kg} / \mathrm{m}^{3}\left(142.6 \mathrm{lb} / \mathrm{ft}^{3}\right)$ for model Core-Loc units.

Due to angular reflection from the model, it was not possible to determine incident wave conditions near the model after the model was constructed. It was therefore necessary to calibrate the basin prior to model construction. The flume was calibrated prior to model construction by placing an array of wave gauges in the location where the model would later be constructed. Signals for the wave generators were created to produce waves larger than would be needed, then run at a range of signal gains to produce varying wave heights. By plotting recorded wave heights against signal gain, a gain could be selected to produce desired incident sea conditions.

To simplify construction and minimize rebuilding time, a concrete core was constructed by shaping a layer of concrete over sand (Photo 1). The concrete core was then covered with a 75-mm-thick (3-in.-thick) layer of gravel scaled to prototype material used for the consolidation pad and breakwater core (Photo 2). The 75-mm-thick (3-in.-thick) layer of gravel ensured that the breakwater would respond correctly to the core material, while the concrete core minimized sorting and rebuilding that would be required in the event of a catastrophic failure of the model. Sheet metal templates used to place the layer of gravel were removed after gravel was in place.

B-stone then was placed on the model in a manner to simulate random stone placement with no attempt to key the stones into a matrix. It is expected that prototype construction will use a backhoe to drop stones into place in a random fashion.

Core-Locs along the toe were placed individually in a uniform pattern as shown in Photo 3. All Core-Locs placed above the toe row were randomly placed. On the harbor side, first row above B-stone also was uniformly placed as at the toe, with all subsequent rows randomly placed.

Placement of Core-Locs on the structure crest followed an "inverted V" (Photo 4). Working from the head back along the crest, Core-Locs were placed in such a manner that they formed a "V" with the point on the crest pointing toward the head. Core-Locs were placed along each side of the structure such that the "V" shape moved along the structure crest from head back along the length of the trunk. This method, recommended by Messrs. Melby and Turk (inventors of the Core-Loc), appeared to produce a more consistent placement of units on the crest and reduced problems with a "seam" that occurs when armor units are placed up each side of the structure and meet at the crest. Where the sides meet, it is difficult to ensure that individual units are keyed into the matrix. 


\section{Results and Discussion}

The physical model was constructed at an undistorted linear scale of 1:23 (model:prototype) using Froude scaling laws. All units used in this report are prototype units unless stated otherwise. With Froude scaling laws, the scaling factor for time units is the square root of linear scaling factor. Therefore, at 1:23 scale, $10 \mathrm{~min}$ in the model represents $48 \mathrm{~min}$ prototype. All test runs were limited to $48 \mathrm{~min}$ (10 min model) to minimize buildup of reflected wave energy in the wave flume. After each run, the flume was allowed to still before the next run was conducted. Core-Locs used in the model scale to $1,360 \mathrm{~kg}(3,000 \mathrm{lb})$ when prototype units are in salt water. All tests were conducted at swl $=+3.2 \mathrm{~m}(+10.5 \mathrm{ft})$ mllw except for tests of toe stability which were conducted at swl $=0.0 \mathrm{~m}(0.0 \mathrm{ft}) \mathrm{mllw}$.

\section{Plan 1}

B-stone in the original plans (with stone as primary armor units) was specified as 140 to $770 \mathrm{~kg}$ ( 300 to $1,700 \mathrm{lb})$ with $W_{50}=340 \mathrm{~kg}(750 \mathrm{lb})$. With the change to Core-Locs, size of the B-stone was reduced to 140 to $270 \mathrm{~kg}$ (300 to $600 \mathrm{lb}$ ). Core-Locs were placed on the structure head and on the sea side of the structure trunk, then across the crest of the trunk and down the harbor side to $+4.0 \mathrm{~m}(+13 \mathrm{ft}) \mathrm{mllw}$. B-stone was used for the underlayer beneath CoreLocs and for outer armor stone on the harbor-side trunk below $+4.0 \mathrm{~m}(+13 \mathrm{ft})$ mllw. A cross section of the model trunk (in prototype units) is shown in Figure 5; a cross section of the model head is shown in Figure 6. Photos 5, 6, and 7 show Plan 1 before testing from sea side, end view, and harbor side, respectively.

No damage was observed during tests with approximately 4,500 waves at wave period of peak energy density $T_{p}=4.1 \mathrm{~s}$ and zeroth moment wave height $H_{m 0}=1.7 \mathrm{~m}(5.5 \mathrm{ft})$ or during three $48-\mathrm{min}$ tests at $T_{p}=7.0 \mathrm{~s}$ and $H_{m 0}=1.7 \mathrm{~m}$ $(5.5 \mathrm{ft})$. During the first $48-\mathrm{min}$ test at $T_{p}=7.0 \mathrm{~s}$ and $H_{m 0}=2.4 \mathrm{~m}(8.0 \mathrm{ft})$, damage was initiated on the harbor-side trunk in the B-stone due to occasional overtopping. During the second 48-min test at $T_{p}=7.0 \mathrm{~s}$ and $H_{m 0}=2.4 \mathrm{~m}$ $(8.0 \mathrm{ft})$, substantial damage occurred to the B-stone on the harbor side as waves overtopping the breakwater caused displacement of B-stone. 


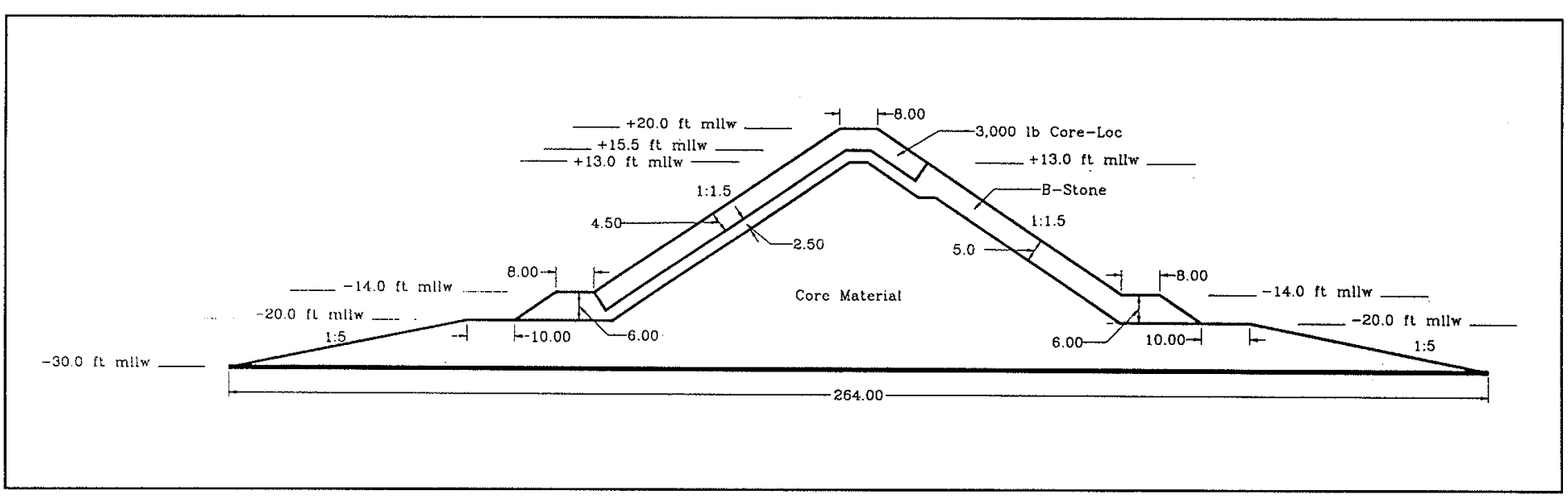

Figure 5. Cross section of breakwater trunk, Plan 1

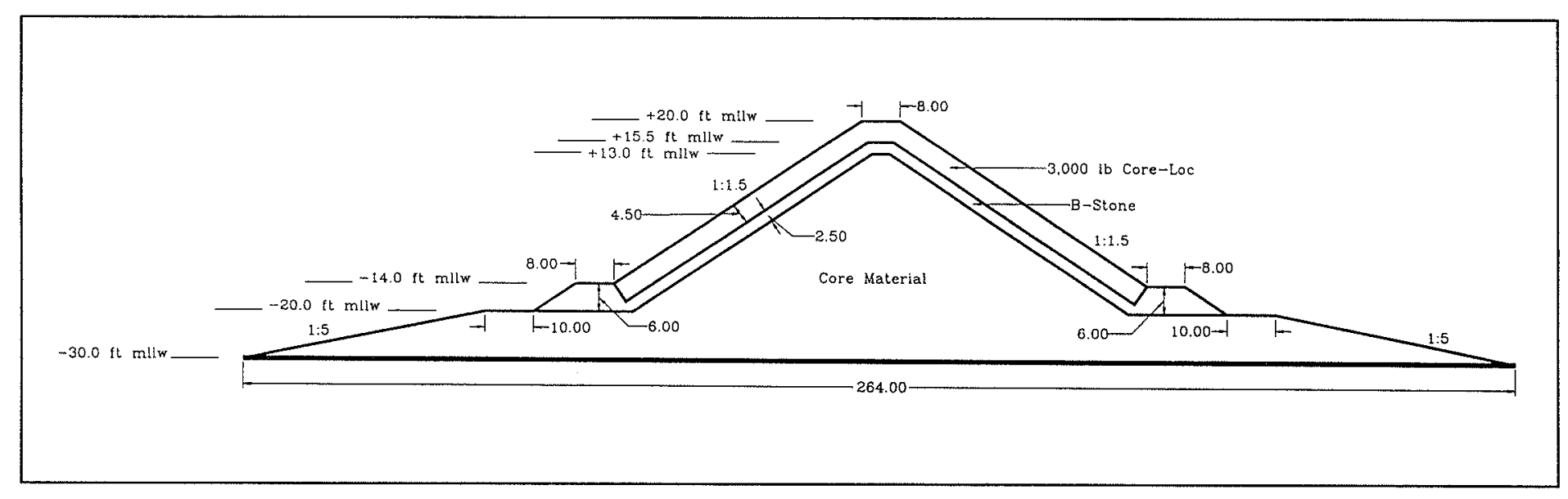

Figure 6. Cross section of breakwater head, Plan 1 
Due to damage sustained during the first two tests at $T_{p}=7.0 \mathrm{~s}$ and $H_{m o}=$ $2.4 \mathrm{~m}(8.0 \mathrm{ft})$, it was decided not to conduct the third test at $T_{p}=7.0 \mathrm{~s}$ and $H_{m o}=2.4 \mathrm{~m}(8.0 \mathrm{ft})$, and instead to conduct tests at $T_{p}=11.0 \mathrm{~s}$ and $H_{m o}=$ $1.7 \mathrm{~m}(5.5 \mathrm{ft})$. During the first 48 -min test at $T_{p}=11.0 \mathrm{~s}$ and $H_{m o}=1.7 \mathrm{~m}$ $(5.5 \mathrm{ft}), \mathrm{B}$-stone sloughed on the harbor-side trunk, causing a massive failure. Core-Locs on the crest and harbor-side trunk were washed down into the area of the slough and damage extended down to core material. The head was undamaged, and there was no damage to the sea-side trunk below core elevation of $4.0 \mathrm{~m} \mathrm{mllw}(+13 \mathrm{ft}$ ). No damage was observed to the toe, apron, or consolidation pad. Photos 8, 9, and 10 show Plan 1 after testing from the sea side, end view, and harbor side, respectively.

\section{Plan 2}

Plan 2 used the same cross sections as Plan 1 (Figures 5 and 6), but replaced B-stone on the harbor-side trunk with larger B-stone weighing 140 to $770 \mathrm{~kg}(300$ to $1,700 \mathrm{lb})$ with $W_{50}=340 \mathrm{~kg}(750 \mathrm{lb})$ to stabilize the harborside trunk. B-stone beneath Core-Locs was not replaced. All Core-Locs were removed from the structure crest and harbor side, but structure head and seaside slope were not rebuilt. Due to settling and compacting of Core-Locs on the head and sea-side slope, 15 additional Core-Locs were required to rebuild the structure crest. The first row of Core-Locs above B-stone on the harborside trunk was not uniformly placed as in Plan 1, but stones were randomly placed for the entire rebuild of the structure.

A 48-min run was conducted at $T_{p}=7 \mathrm{sec}$ and $H_{m 0}=1.7 \mathrm{~m}(5.5 \mathrm{ft})$ to shake down the structure. No movement of armor units was observed on the model. The model crest was occasionally overtopped by green water, but no damage to B-stone was observed.

The structure then was tested at $T_{p}=7 \mathrm{sec}$ and $H_{m 0}=2.4 \mathrm{~m}(8.0 \mathrm{ft})$ with runs of 48-min duration. One Core-Loc was displaced from the harbor side of the head at approximately $0.0 \mathrm{~m}(0.0 \mathrm{ft}) \mathrm{mllw}$ by wave action diffracting around the head during the first run at $T_{p}=7 \mathrm{~s}$ and $H_{m 0}=2.4 \mathrm{~m}(8.0 \mathrm{ft})$; no other movement of armor units was observed until a sudden failure during the second run. B-stone was washed out at the interface between Core-Locs and B-stone at $+4.0 \mathrm{~m}(+13 \mathrm{ft}) \mathrm{m}$ llw from the wall to about one half distance to the model head, leaving the toe of the Core-Locs unsupported in this area. A

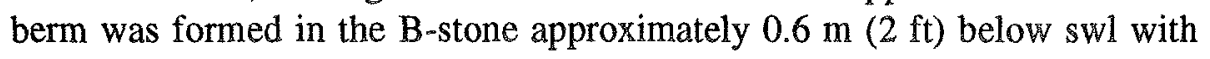
stone that had washed out from the toe of the Core-Locs. Below the berm, B-stone appeared undamaged.

With the exception of one Core-Loc from the harbor-side head mentioned above, no damage to Core-Locs was observed until midway through the second run at $T_{p}=7 \mathrm{sec}$ and $H_{m 0}=2.4 \mathrm{~m}(8.0 \mathrm{ft})$. A group of three extreme waves produced significant overtopping and caused a massive sliding failure from the crest down the harbor side of the structure. The failure extended 
from the wall about halfway out toward the model head. Both Core-Locs and underlying B-stone were washed off the crest, exposing core material. The head was undamaged, and there was no damage to the sea-side trunk below core elevation of $+4.0 \mathrm{~m}(+13 \mathrm{ft})$ mllw. No damage was observed to the toe, apron, or consolidation pad.

During tests at $T_{p}=7 \mathrm{sec}$ and $H_{m o}=2.4 \mathrm{~m}(8.0 \mathrm{ft})$, waves overtopping the structure would form a plunging breaker that would crash onto the harbor side. Frequently, overtopping waves would plunge completely over the model to fall harmlessly into water on the harbor side. Occasionally, overtopping waves would plunge directly onto the interface between Core-Locs and B-stone, causing the observed undermining of B-stone. Waves falling farther out from the structure were cushioned by water over the B-stone lower on the structure and therefore caused no damage.

During tests on Plan 2, it was noticed that undermining of Core-Locs on the harbor side was somewhat more pronounced immediately adjacent to the wall. This had not been true during tests on Plan 1, and no significant wall effects had been noticed during any test run. However, it was decided to place a strip of rubberized mat ("horsehair") over the structure adjacent to the wall to ensure that no wall effects would be present during future tests.

\section{Plan 3}

Plan 3 used the same cross section as Plans 1 and 2 for the head (Figure 6), but extended Core-Locs on the harbor-side trunk from the crest down to $0.0 \mathrm{~m}$ $(0.0 \mathrm{ft}) \mathrm{mllw}$ (Figure 7$)$. In Plan 1, Core-Locs extended from the crest only

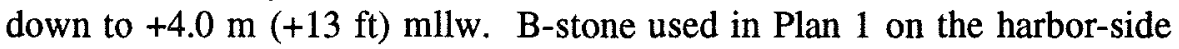
trunk again was used on Plan 3, replacing the larger B-stone used on Plan 2. NPA expressed concerns about availability of larger B-stone and preferred a design using smaller stone.

The sea-side slope and structure head were not rebuilt after Plan 2 testing. All Core-Locs were removed from the crest and harbor-side trunk, and the larger-sized B-stone on the harbor-side trunk were removed. The crest and harbor-side trunk were then rebuilt. Plan 3 used 143 more Core-Loc units than Plan 2 due to placing the Core-Locs further down from the crest on the harborside trunk. A strip of horsehair $0.15 \mathrm{~m}(0.5 \mathrm{ft})$ wide was placed over the structure along the wall from the sea-side toe to the harbor-side toe to protect units near the wall from wall effects. Photos 11 and 12 show the sea side and harbor side, respectively, of Plan 3 before testing.

Six runs of 48 min each (total of about 4,500 waves) were conducted at $T_{p}=4.1 \mathrm{sec}$ and $H_{m 0}=1.7 \mathrm{~m}(5.5 \mathrm{ft})$ to test design wave conditions. No movement of stone or Core-Locs was detected. Three runs of $48 \mathrm{~min}$ each were conducted at $T_{p}=7.0 \mathrm{sec}$ and $H_{m 0}=1.7 \mathrm{~m}(5.5 \mathrm{ft})$, three runs of $48 \mathrm{~min}$ each were conducted at $T_{p}=11.0 \mathrm{sec}$ and $H_{m 0}=1.7 \mathrm{~m}(5.5 \mathrm{ft})$, then three runs 


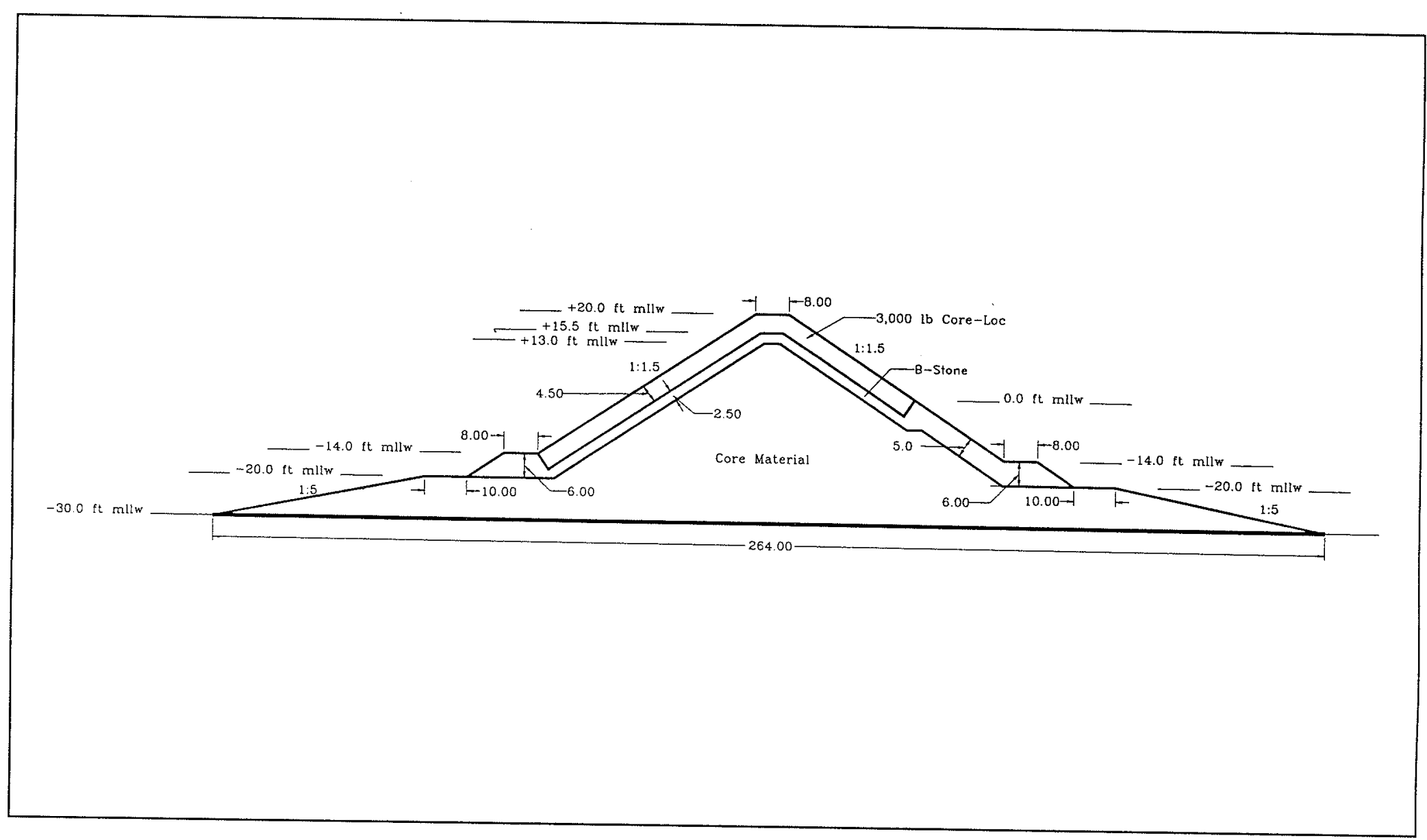

Figure 7. Cross section of breakwater trunk, Plan 3 
of $48 \mathrm{~min}$ each were conducted at $T_{p}=14.0 \mathrm{sec}$ and $H_{m 0}=1.7 \mathrm{~m}(5.5 \mathrm{ft})$. Again, no movement was detected on the model.

Three runs of $48 \mathrm{~min}$ each were conducted at $T_{p}=14.0 \mathrm{sec}$ and $H_{m 0}=$ $2.1 \mathrm{~m}(7.0 \mathrm{ft})$. During the third run, the structure failed when heavy overtopping pushed Core-Loc units down the harbor side of the trunk with enough force to push the B-stone on down the slope in front of the Core-Locs. There was no evidence of undermining. The 14-sec waves overtopped the structure trunk as a surging breaker, causing a very heavy downrush on the harbor side. Because the B-stones were placed by dumping, they were not interlocked into a matrix as is the case with individually placed and seated armor units. The B-stone therefore had little resistance to sliding. Hydrodynamic forces on the Core-Locs were sufficient to push the B-stone downslope and cause a slumping failure in the Core-Locs.

Until the failure occurred, the only movement observed was one Core-Loc displaced from the harbor-side head. The displaced unit was the same unit displaced in Plan 2. During the rebuild of the crest for Plan 3, the Core-Loc displaced from the harbor-side head was replaced into its original location in the matrix, but apparently was not adequately anchored. Photos 13 and 14 show sea-side and harbor-side views, respectively, of Plan 3 after testing. Photo 15 is another harbor-side view of Plan 3 after testing taken at a higher angle to better display the damage.

\section{Plan 3R}

A repeat test of Plan 3 was conducted to verify results observed during the original test of Plan 3. There were no changes made to Plan 3 for the repeat test (Plan 3R). All Core-Locs on the crest and harbor-side trunk, underlying $\mathrm{B}$-stone, and exposed B-stone on the harbor-side trunk were removed and replaced. In addition, the structure head was rebuilt from the area where a Core-Loc was displaced during tests on Plans 2 and 3 back to the B-stone on the harbor-side trunk. Rebuilding this portion of the structure head ensured that the displaced Core-Loc was properly seated for the repeat test.

Due to settling of Core-Loc units on the sea-side slope and structure head (which were not rebuilt), the repeat test required 13 additional Core-Locs, of which only 9 were available at that time. Because horsehair was placed over the structure along the flume wall, Core-Locs were not required immediately adjacent to the wall. Therefore, a hole was left along the crest under the horsehair. Lead weights were placed over the hole to ensure that all CoreLocs were held in place.

A 48-min run with $H_{m 0}=1.7 \mathrm{~m}(5.5 \mathrm{ft})$ was conducted at each of $T_{p}=$ $4.1 \mathrm{sec}, 7.0 \mathrm{sec}, 11.0 \mathrm{sec}$, and $14.0 \mathrm{sec}$. The model then was tested with three runs of $48 \mathrm{~min}$ each at $T_{p}=7.0 \mathrm{sec}$ and $H_{m 0}=2.4 \mathrm{~m}(8.0 \mathrm{ft})$. No movement was observed on the model. 
The model next was tested with 48 -min runs at $T_{p}=11.0 \mathrm{sec}$ and $H_{m 0}=$ $2.4 \mathrm{~m}(8.0 \mathrm{ft})$. No movement was observed during the first run, but a hole in the Core-Locs was washed out during the second run. The hole developed suddenly when several Core-Locs were washed out of the matrix on the harbor-side trunk between swl at $+3.2 \mathrm{~m}(+10.5 \mathrm{ft}) \mathrm{mllw}$ and the toe of the Core-Locs above the B-stone at $0.0 \mathrm{~m}(0.0 \mathrm{ft}) \mathrm{mllw}$. All tests were halted at this point to allow the structure to be viewed by personnel visiting from NPA. Photo 16 shows damage that occurred to Plan 3R during the second run at $T_{p}=11.0 \mathrm{sec}$ and $H_{m 0}=2.4 \mathrm{~m}(8.0 \mathrm{ft})$.

Without rebuilding the structure, numerous short test runs were conducted to demonstrate the model to NPA personnel. No noticeable movement was observed during short tests at swl $=+3.2 \mathrm{~m}(+10.5 \mathrm{ft}), H_{m 0}=1.7 \mathrm{~m}(5.5 \mathrm{ft})$, and $T_{p}=4.1 \mathrm{sec}, 7.0 \mathrm{sec}$, and $11.0 \mathrm{sec}$. Water level then was lowered to $\mathrm{swl}=$ $0.0 \mathrm{~m}(0.0 \mathrm{ft}) \mathrm{mllw}$ to demonstrate toe stability with short tests at $H_{m 0}=1.7 \mathrm{~m}$ $(5.5 \mathrm{ft})$ and $T_{p}=4.1 \mathrm{sec}$, and $H_{m 0}=2.1 \mathrm{~m}(7.0 \mathrm{ft})$ at $T_{p}=7.0 \mathrm{sec}$ and $14 \mathrm{sec}$. Again, no movement was observed. The water level then was returned to $\mathrm{swl}=+3.2 \mathrm{~m}(+10.5 \mathrm{ft}) \mathrm{mllw}$.

At swl $=+3.2 \mathrm{~m}(+10.5 \mathrm{ft})$ mllw, a short demonstration run was conducted at $T_{p}=14 \mathrm{sec}$ and $H_{m 0}=1.7 \mathrm{~m}(5.5 \mathrm{ft})$ with no noticeable movement on the structure, but the structure failed during a test at $T_{p}=14 \mathrm{sec}$ and $H_{m 0}=2.1 \mathrm{~m}$ $(7.0 \mathrm{ft})$. Heavy overtopping caused armor units on the harbor-side trunk above swl to slough, exposing the underlayer.

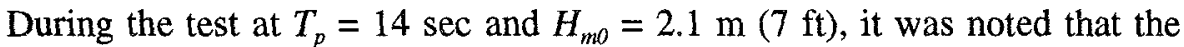
water surface elevation was higher near the wall on the sea side of the structure due to a flume effect. This was only observed during tests at $T_{p}=14 \mathrm{sec}$. During drawdown between a group of large waves, a strong current developed around the structure head as water was pulled from the harbor end of the flume. This current then diffracted around the breakwater head and built up along the wall as the next wave reached the breakwater. Because of the elevated water surface near the wall, overtopping was significantly greater than would be expected on the prototype. Failures observed in tests of Plans 3 and 3R therefore are thought to have been caused in part by a flume effect. Failures observed during tests of Plans 1 and 2 occurred during tests with shorter wave periods where no flume effect was observed.

\section{Plan 4}

Plan 4 was built in the same configuration as Plan 3 and Plan 3R. All Core-Locs were removed from the model before rebuilding, the underlayer was reshaped as necessary, and Core-Locs were replaced. Core-Locs were apparently placed with a slightly higher packing density, as 16 more Core-Locs were required than were used on Plan 3R. 
Model crest elevation was surveyed after construction. The crest averaged $+18.53 \mathrm{ft}$ mllw, rather than the estimated $+20.0 \mathrm{ft}$ mllw. The top of the underlayer was at the correct elevation; no attempt was made to build the Core-Locs to a specific elevation, they were simply placed over the underlayer in a manner replicating prototype construction.

Rubberized matting wave absorber (horsehair) was placed in vertical panels $0.46 \mathrm{~m}$ (18 in.) out from the wall extending from the crest to the toe of the breakwater on both the sea and harbor sides. The panels restricted flow around the head and reflection from the wall to minimize wall effects. Visual observations indicated that the wall effects previously noticed on 14-sec waves were greatly reduced, but not eliminated. Any damage within $0.46 \mathrm{~m}$ (18 in.) of the wall is therefore considered suspect, but beyond the absorber (toward the head), there was no indication of flume effects.

Initial tests of Plan 4 were conducted with swl $=0.0 \mathrm{~m}(0.0 \mathrm{ft})$ mllw to ensure that the structure toe could be tested before the structure was failed at higher water. Three tests of 48-min duration each were conducted at $T_{p}=4.1$ $\mathrm{sec}$ and $H_{m 0}=1.7 \mathrm{~m}(5.5 \mathrm{ft})$, followed by three tests at $T_{p}=7.0 \mathrm{sec}$ and three tests at $T_{p}=14 \mathrm{sec}$, all at $H_{m 0}=1.7 \mathrm{~m}(5.5 \mathrm{ft})$. No movement was observed on the structure.

Water elevation then was raised to swl $=+3.2 \mathrm{~m}(+10.5 \mathrm{ft}) \mathrm{mllw}$. Three tests of 48-min duration each were conducted at each of $T_{p}=4.1 \mathrm{sec}, 7.0 \mathrm{sec}$, $11 \mathrm{sec}$, and $14 \mathrm{sec}$, all at $H_{m 0}=1.7 \mathrm{~m}(5.5 \mathrm{ft})$. The structure was overtopped during tests at $T_{p}=11 \mathrm{sec}$ and $14 \mathrm{sec}$, but no movement was observed on the structure.

At the request of NPA, water surface elevation then was lowered to $+2.6 \mathrm{~m}$ $(+8.5 \mathrm{ft})$ mllw. Tests at $\mathrm{swl}=+2.6 \mathrm{~m}(+8.5 \mathrm{ft})$ mllw were not included in the original scope of work, and the wave flume had not been calibrated at this depth. Due to diffraction and reflection from the structure, it was not possible to accurately determine incident wave conditions with the structure in place. Signals sent to the wave generator therefore could only be estimated to produce the correct wave heights. Although wave heights reported for this depth are assumed to be reasonably accurate, it should be noted that wave heights at $\mathrm{swl}=+2.6 \mathrm{~m}(+8.5 \mathrm{ft})$ mllw were estimated, not calibrated.

With swl $=+2.6 \mathrm{~m}(+8.5 \mathrm{ft})$ mllw, three test runs of 48-min duration each were conducted at each of $T_{p}=11 \mathrm{sec}$ and $14 \mathrm{sec}$, with $H_{m 0}=1.7 \mathrm{~m}(5.5 \mathrm{ft})$. The structure was overtopped only during tests with $T_{p}=14 \mathrm{sec}$. No movement was observed on the structure.

Water level then was returned to $\mathrm{swl}=+3.2 \mathrm{~m}(+10.5 \mathrm{ft}) \mathrm{mllw}$ for three runs of $48 \mathrm{~min}$ duration each at $T_{p}=14 \mathrm{sec}$ and $H_{m 0}=2.1 \mathrm{~m}(7.0 \mathrm{ft})$. The structure was heavily overtopped, causing some displacement of " $B$ " stone on the harbor side. No movement of Core-Locs was noticed. 
At the request of NPA, water surface elevation then was raised to $+3.8 \mathrm{~m}$ $(+12.5 \mathrm{ft})$ mllw. Tests at $\mathrm{swl}=+3.8 \mathrm{~m}(+12.5 \mathrm{ft}) \mathrm{mllw}$ were not included in the original scope of work, and the flume had not been calibrated at this depth. Similar to tests at swl $=+2.6 \mathrm{~m}(+8.5 \mathrm{ft})$ mllw, generated wave heights at $\mathrm{swl}=+3.8 \mathrm{~m}(+12.5 \mathrm{ft})$ mllw could only be estimated but are assumed to be reasonably accurate.

With swl $=+3.8 \mathrm{~m}(+12.5 \mathrm{ft})$ milw, three test runs of 48 -min duration each were conducted at each of $T_{p}=11 \mathrm{sec}$ and $14 \mathrm{sec}$, with $H_{m 0}=1.7 \mathrm{~m}(5.5 \mathrm{ft})$. Overtopping was observed during each test run, but no movement was observed on the structure.

Photos 17, 18, and 19 show sea-side, end, and harbor-side views, respectively, of Plan 4 after testing.

\section{Plan 5}

Plan 5 used armor stone instead of Core-Locs for primary armoring of the structure. All Core-Locs were removed from the structure and the underlayer was smoothed and reshaped as necessary. A double layer of armor stone with $W_{s o}=1,450 \mathrm{~kg}(3,200 \mathrm{lb})$ was placed over the B-stone underlayer. Crest elevations of the structure core and underlayer were the same as in Plans 1, 2, 3 , and 4 , but the double layer of armor stones raised the final crest elevation higher than the single layer of Core-Locs used on earlier test configurations. Stones were placed in a manner similar to dropping each stone individually from a backhoe, and no attempt was made to specially place or key the stones. Stones used on the model were more uniform in size than would be expected on the prototype, with model stones typically within \pm 10 percent of $W_{50}$. Figure 8 shows a cross section of the Plan 5 trunk; Figure 9 shows a cross section of the Plan 5 head. The vertical panels of rubberized matting used in Plan 4 were used again in Plan 5. Photos 20, 21, and 22 show sea-side, end, and harbor-side views, respectively, of Plan 5 before testing.

At $\mathrm{swl}=+3.2 \mathrm{~m}(+10.5 \mathrm{ft}) \mathrm{mllw}$, three test runs of $48 \mathrm{~min}$ duration each were conducted at each of $T_{p}=4.1 \mathrm{sec}, 11 \mathrm{sec}$, and $14 \mathrm{sec}$, all with $H_{m 0}=$ $1.7 \mathrm{~m}(5.5 \mathrm{ft})$. No movement was observed on the structure during tests at $T_{p}=4.1 \mathrm{sec}$. During the third test at $T_{p}=11 \mathrm{sec}$, one stone was displaced on the harbor-side trunk by waves overtopping the structure. During the same run, two additional stones were displaced on the harbor-side trunk but were located between the flume wall and vertical wave absorber panels and are not counted as damage. During the first test at $T_{p}=14 \mathrm{sec}$, two stones were dislodged on the sea-side trunk, but were located between the wall and absorber panels.

During the second test run at $T_{p}=14 \mathrm{sec}$ and $H_{m 0}=1.7 \mathrm{~m}(5.5 \mathrm{ft})$, several stones were dislodged on the harbor side. The dislodged stones generally were 


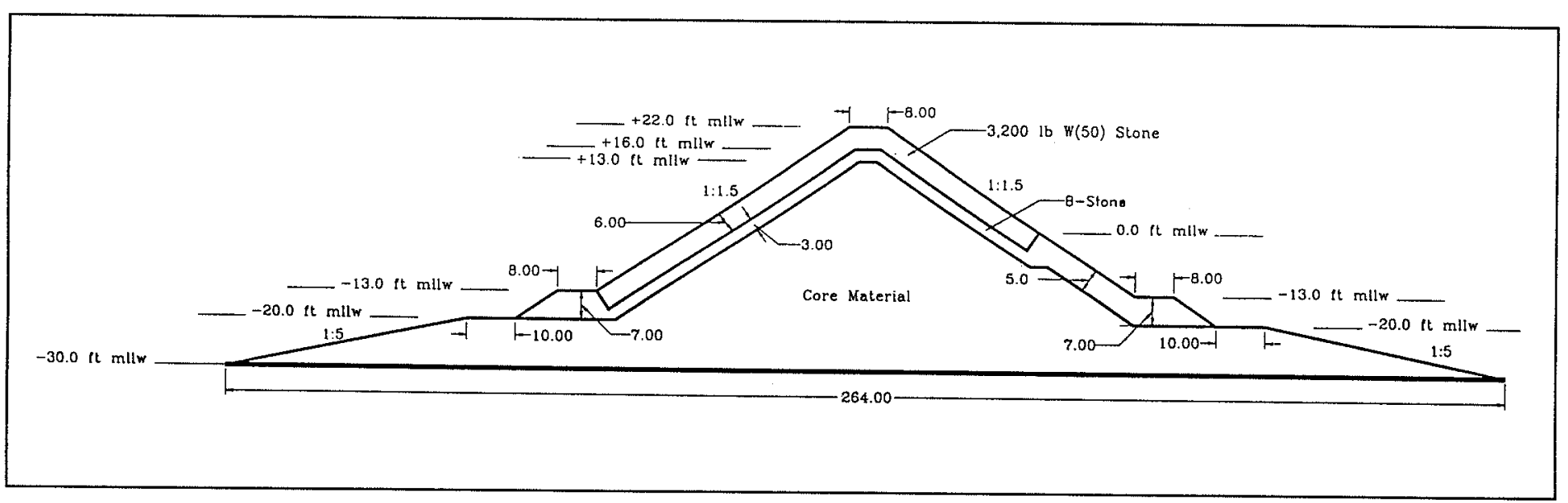

Figure 8. Cross section, breakwater trunk, Plan 5

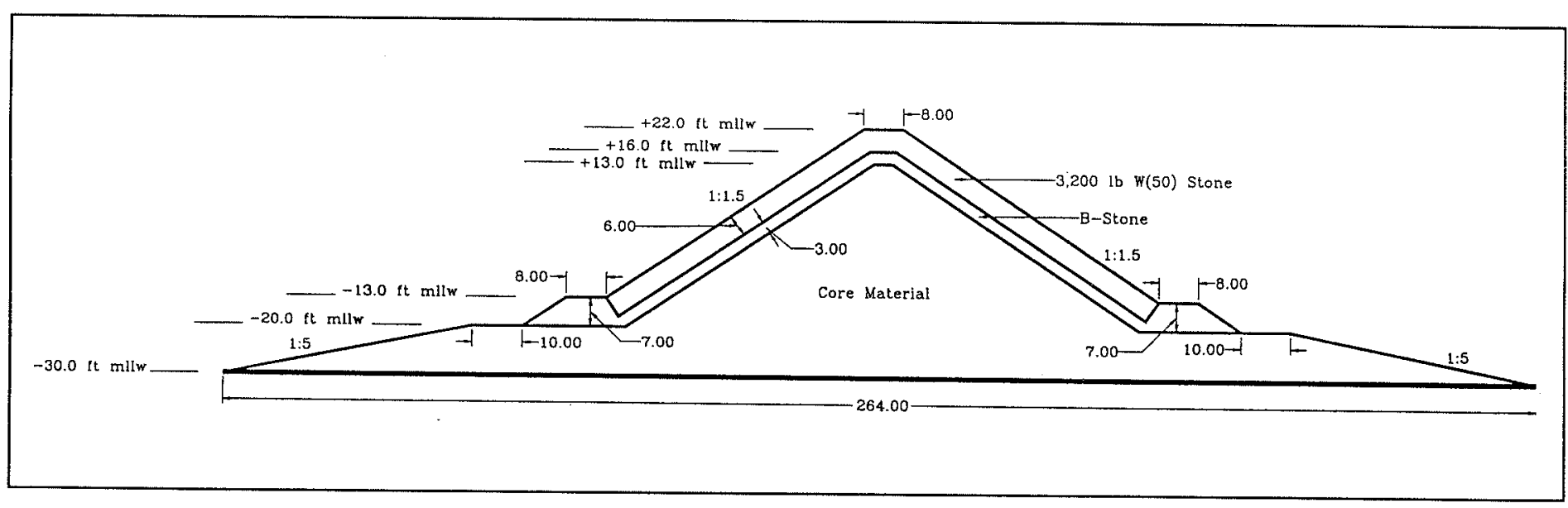

Figure 9. Cross section, breakwater head, Plan 5 
located along a line extending down on the harbor side from the radial point at the structure head, and were located both above and below swl. Damage appeared to be caused by wave action around the breakwater head rather than by overtopping.

Three test runs next were conducted at $T_{p}=14 \mathrm{sec}$ and $H_{m 0}=2.1 \mathrm{~m}$ $(7.0 \mathrm{ft})$. One stone was dislocated on the sea-side trunk during the first run. Also during the first run, several stones were dislodged from the head and washed around to the harbor side below the radial point, causing a scour hole to develop with a diameter of four to five stones. The scour hole developed in an area near swl and about 45 deg back toward the harbor side from the point of the head. Structural integrity was not threatened by the scour hole at this time, but further development of the scour hole could cause a sloughing failure on the head between the crest and swl. The scour hole stabilized after the first run at $T_{p}=14 \mathrm{sec}$ and $H_{m 0}=2.1 \mathrm{~m}(7.0 \mathrm{ft})$, and there was little additional damage during the second and third runs.

Water surface elevation next was lowered to $0.0 \mathrm{~m}(0.0 \mathrm{ft}) \mathrm{mllw}$ to test toe stability. Three test runs of 48-min duration each were conducted with $T_{p}=14$ sec and $H_{m 0}=1.7 \mathrm{~m}(5.5 \mathrm{ft})$. During the course of the three tests, three stones were dislodged from the slope on the head and one from the sea-side trunk. The structure remained in stable condition. Photos 23, 24, and 25 show the sea side, end view, and harbor side, respectively, of Plan 5 after testing.

\section{Plan 5R}

Plan 5 was repeated to ensure consistency in the results. The armor layer was removed, the B-stone underlayer was reshaped as needed, and the armor layer was rebuilt.

At swl $=+3.2 \mathrm{~m}(+10.5 \mathrm{ft})$ mllw, two stones were dislodged on the head during three test runs with $T_{p}=4.1 \mathrm{sec}$ and $H_{m 0}=1.7 \mathrm{~m}(5.5 \mathrm{ft})$, and three stones were dislodged during three runs at $T_{p}=7.0 \mathrm{sec}$ and $H_{m 0}=1.7 \mathrm{~m}$ $(5.5 \mathrm{ft})$. Each run lasted $48 \mathrm{~min}$.

The structure suffered minor damage during the first of three test runs of 48-min duration each with $T_{p}=14 \mathrm{sec}$ and $H_{m 0}=1.7 \mathrm{~m}(5.5 \mathrm{ft})$. During the first run, two stones were lost on the sea-side trunk from near swl which, combined with one or two stones lost from the same area in previous tests, created a small scour hole in the outer armor layer. More significantly, five stones were lost on the head near the intersection of the head and trunk on the harbor side, creating a scour hole near swl. One additional stone was lost on the head, and minor losses were noted between the wall and the vertical panels of rubberized mat. No additional losses were noted during the second and third tests at $T_{p}=14 \mathrm{sec}$ and $H_{m 0}=1.7 \mathrm{~m}(5.5 \mathrm{ft})$. 
The scour hole that developed on the head during the first run at $T_{p}=$ $14 \mathrm{sec}$ and $H_{m 0}=1.7 \mathrm{~m}(5.5 \mathrm{ft})$ enlarged during three runs of 48 -min duration each at $T_{p}=14 \mathrm{sec}$ and $H_{m 0}=2.1 \mathrm{~m}(7.0 \mathrm{ft})$. Most of the scour hole was just under swl and extended from near the point of the head (along an extension of the crestline) to a line extending from the radial point towards the harbor side perpendicular to the crestline. A smaller scour hole was located just below swl on the head seaward of a line extending the crestline onto the head. Both scour holes were only in the outer single layer of armor stones. A few isolated stones were also displaced, causing minor additional damage to the structure. Although the structure appeared to be stable at this point, additional development of the scour holes could lead to failures on the structure head.

The final three test runs of the St. Herman Harbor stability test series were conducted at swl $=0.0 \mathrm{~m}(0.0 \mathrm{ft})$ mllw with $T_{p}=14 \mathrm{sec}$ and $H_{m 0}=1.7 \mathrm{~m}$ $(5.5 \mathrm{ft})$. Each of the last three runs was of 48-min duration. Three additional stones were lost from the scour hole on the sea-side trunk with minor additional damage observed elsewhere on the structure. No damage was detected on the structure toe or consolidation pad. Photos 26, 27, and 28 show the sea side, end view, and harbor side, respectively, of Plan $5 \mathrm{R}$ after testing.

\section{Conservatism}

Conservatism was built into the model test results in several ways. The floor of the wave flume was located at $-9.1 \mathrm{~m}(-30 \mathrm{ft}) \mathrm{mllw}$, whereas the base of the consolidation pad in the prototype is about $-18.3 \mathrm{~m}(-60 \mathrm{ft}) \mathrm{mllw}$. Although calibration of the flume ensured that wave heights at the structure were correct, the shallower water in the wave flume tends to steepen incident waves, which creates a more damaging breaking wave environment.

As noted above during discussion of Plan 3, flume effects were observed during tests with wave periods of $T_{p}=14 \mathrm{sec}$ that increased water surface elevation near the flume wall, increasing the amount of overtopping. Although this flume effect was largely corrected by the addition of vertical panels of rubberized matting, some flume effect remained.

Reflected wave energy from flume walls and from the structure increased the wave energy environment in the flume. Using multiple, short test runs and allowing the flume to still between runs prevented an excessive buildup of reflected energy, but some additional wave energy due to reflection is expected.

Armor stone used on Plan 5 was more uniform in weight than would be expected on the prototype. Uniform stone sizes tend to form a less stable matrix than is formed by stones with a wider gradation.

All physical model tests were conducted with incident waves normal to the breakwater center line. Long-period waves on the prototype are expected at an angle of $30 \mathrm{deg}$ off the normal. 


\section{Conclusions}

Core-Loc armor units of $1,350 \mathrm{~kg}(3,000 \mathrm{lb})$ each were tested and shown to provide a stable armoring of the proposed St. Herman's Harbor breakwater on both the head and trunk when placed in the configuration tested in Plan 4 and when subjected to the wave environment replicated in these tests. B-stone with $\mathrm{W}_{50}=135 \mathrm{~kg}(300 \mathrm{lb})$ was found to provide a satisfactory underlayer to the Core-Locs. B-stone with $\mathrm{W}_{50}=135 \mathrm{~kg}(300 \mathrm{lb})$ was also used successfully as the outer armor layer on the harbor-side trunk below swl.

Armor stone with $\mathrm{W}_{50}=1,450 \mathrm{~kg}(3,200 \mathrm{lb})$ was successfully tested in place of the Core-Loc armor units. The structure suffered more damage during tests with armor stone than during tests with Core-Locs, but structural integrity was not threatened. Extended or repeated exposure to severe conditions reproduced in the wave flume may cause a scour hole that would threaten the structure if the prototype were built in the configuration tested.

Extending the B-stone as outer armor layer on the harbor-side trunk above swl was not satisfactory. Waves overtopping the structure plunged directly down on the area between crest and swl on the harbor side of the structure, displacing any exposed B-stone in the area. By extending the Core-Loc armor units or armor stones from the crest to swl on the harbor side, waves overtopping the structure plunged onto the heavier armor units without damage to the structure.

According to NPA, 1,350-kg (3,000-lb) Core-Locs were the most costeffective due to reduced handling costs, although $500-\mathrm{kg}(1,100-\mathrm{lb})$ Core-Locs would provide adequate stability. However, flow forces are higher on larger Core-Locs. Waves overtopping the structure and plunging on the harbor side tended to push Core-Locs downslope into the B-stone. Because B-stone was placed by dumping (as opposed to individual placement into a keyed matrix), the B-stone had little resistance to downward pressure from Core-Locs, leading to a sloughing failure (Plans 2, 3, and 3R). Although Core-Locs tested provided adequate stability, use of smaller Core-Locs may provide greater stability due to lower downrush forces on each unit. Use of smaller units was not tested in this test series. 




Photo 1. Construction of sand and concrete model core

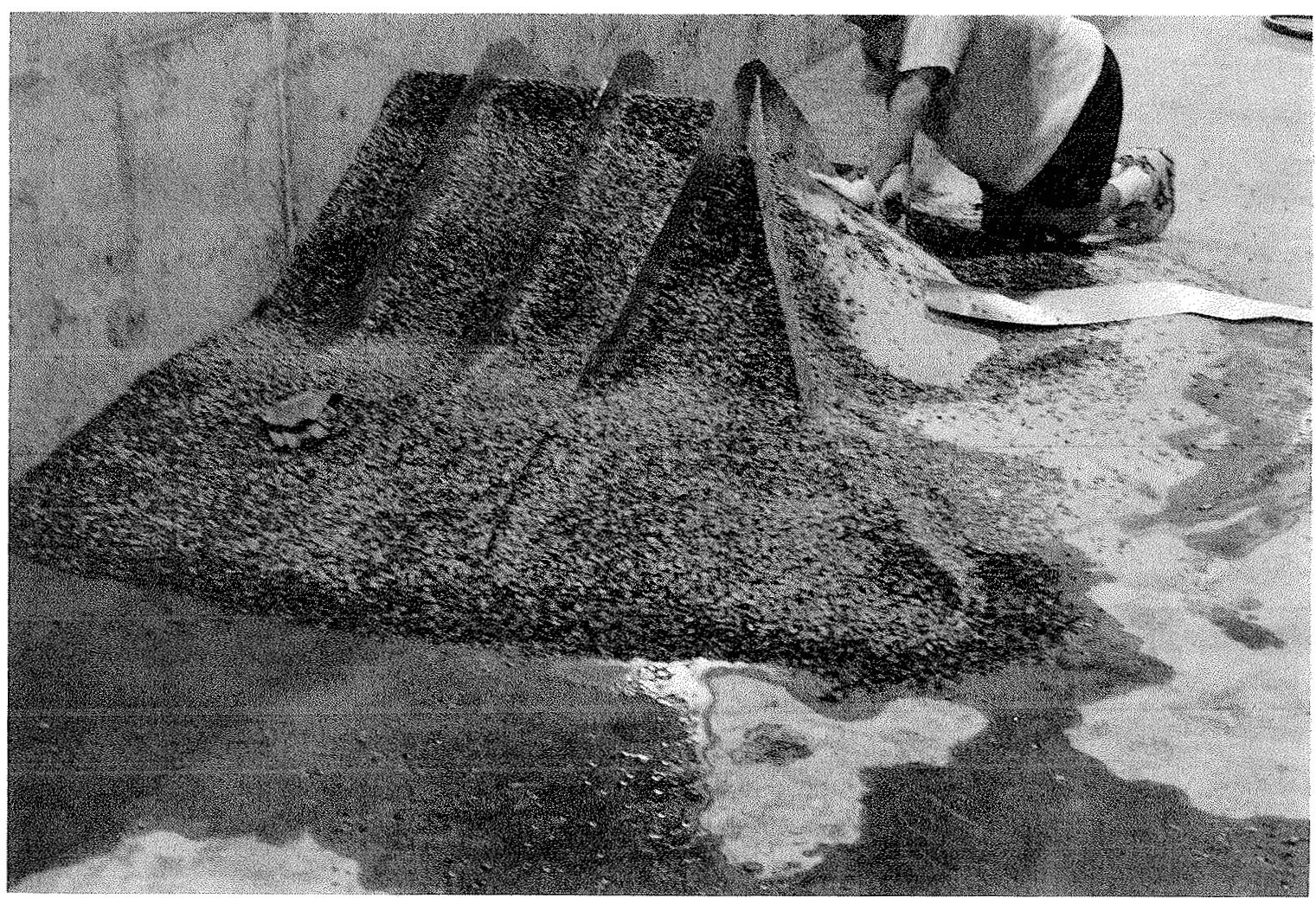

Photo 2. Placement of gravel layer over model core 




Photo 3. Placement of Core-Loc concrete armor units on model toe

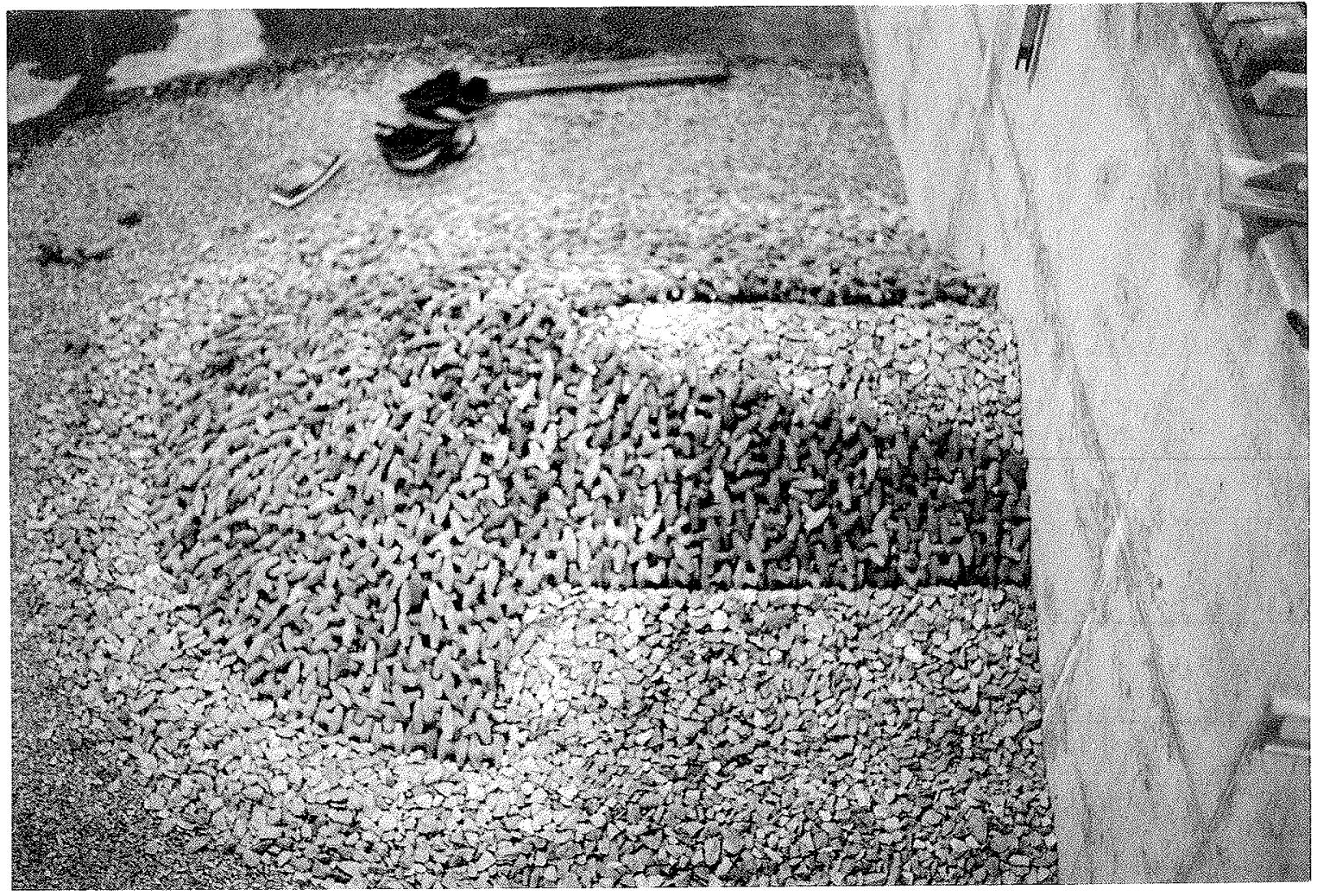

Photo 4. "Inverted V" placement technique for concrete armor units 


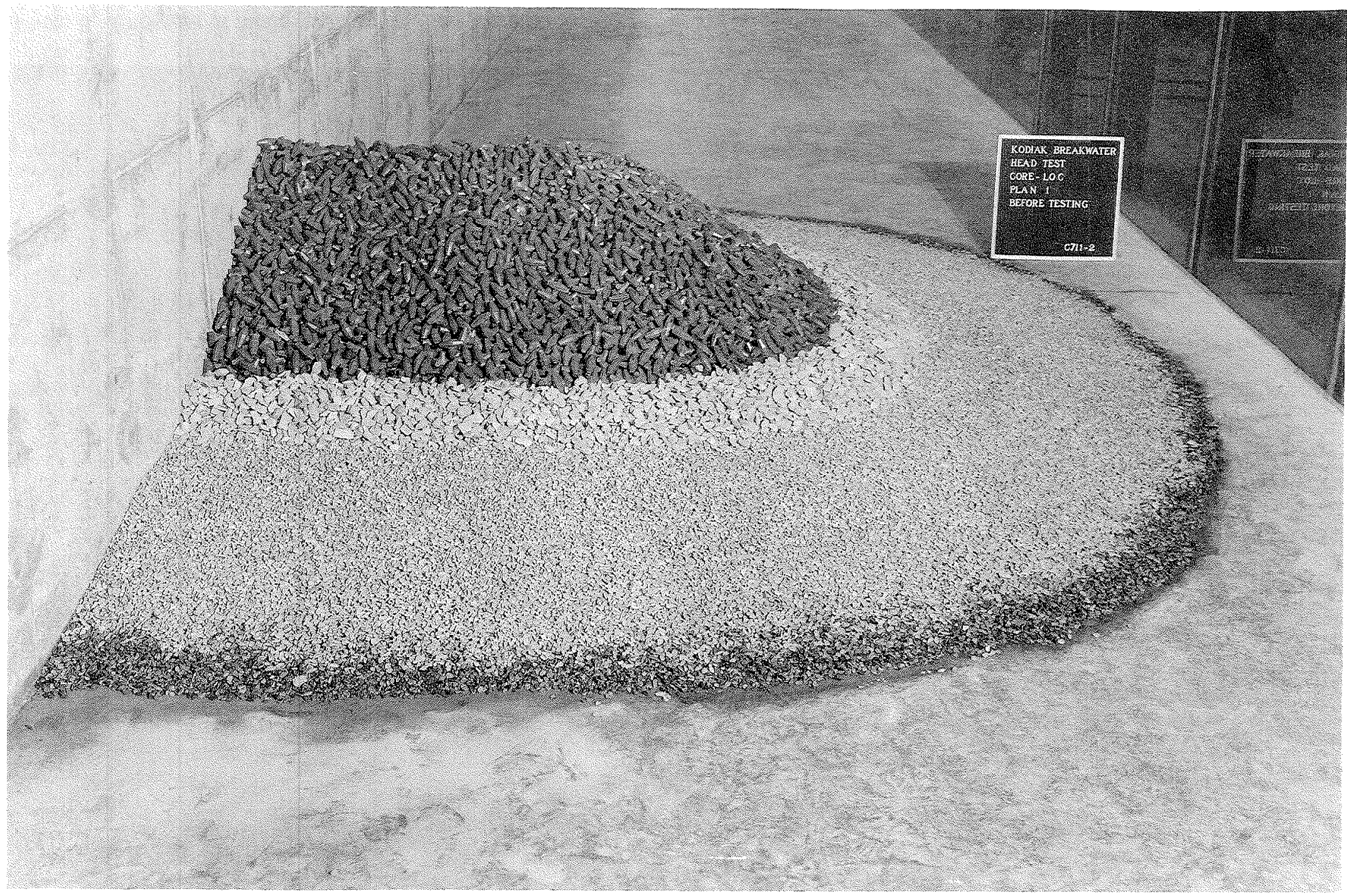

Photo 5. Sea-side view of model breakwater Plan 1 before testing 


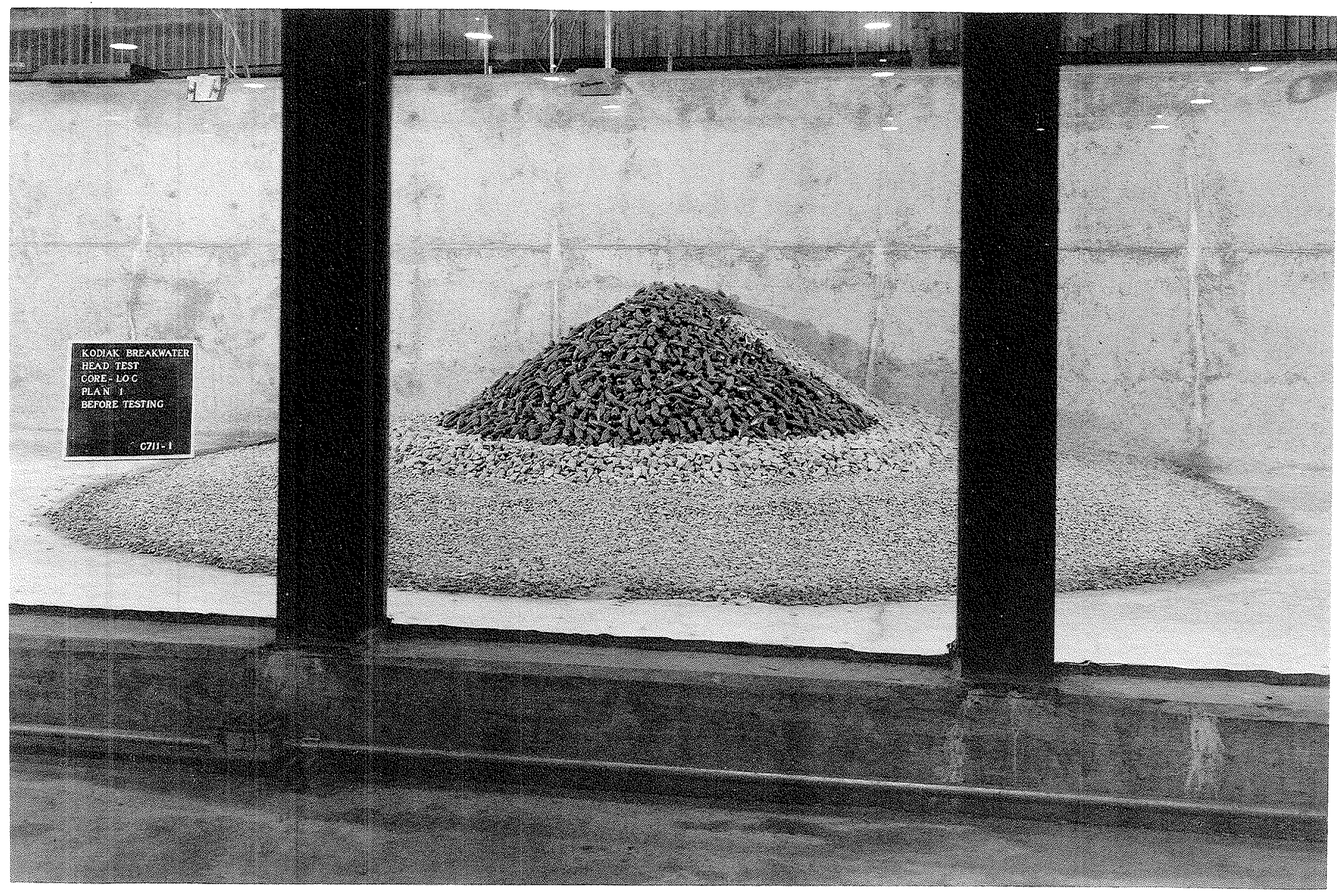

Photo 6. End view of model breakwater Plan 1 before testing 


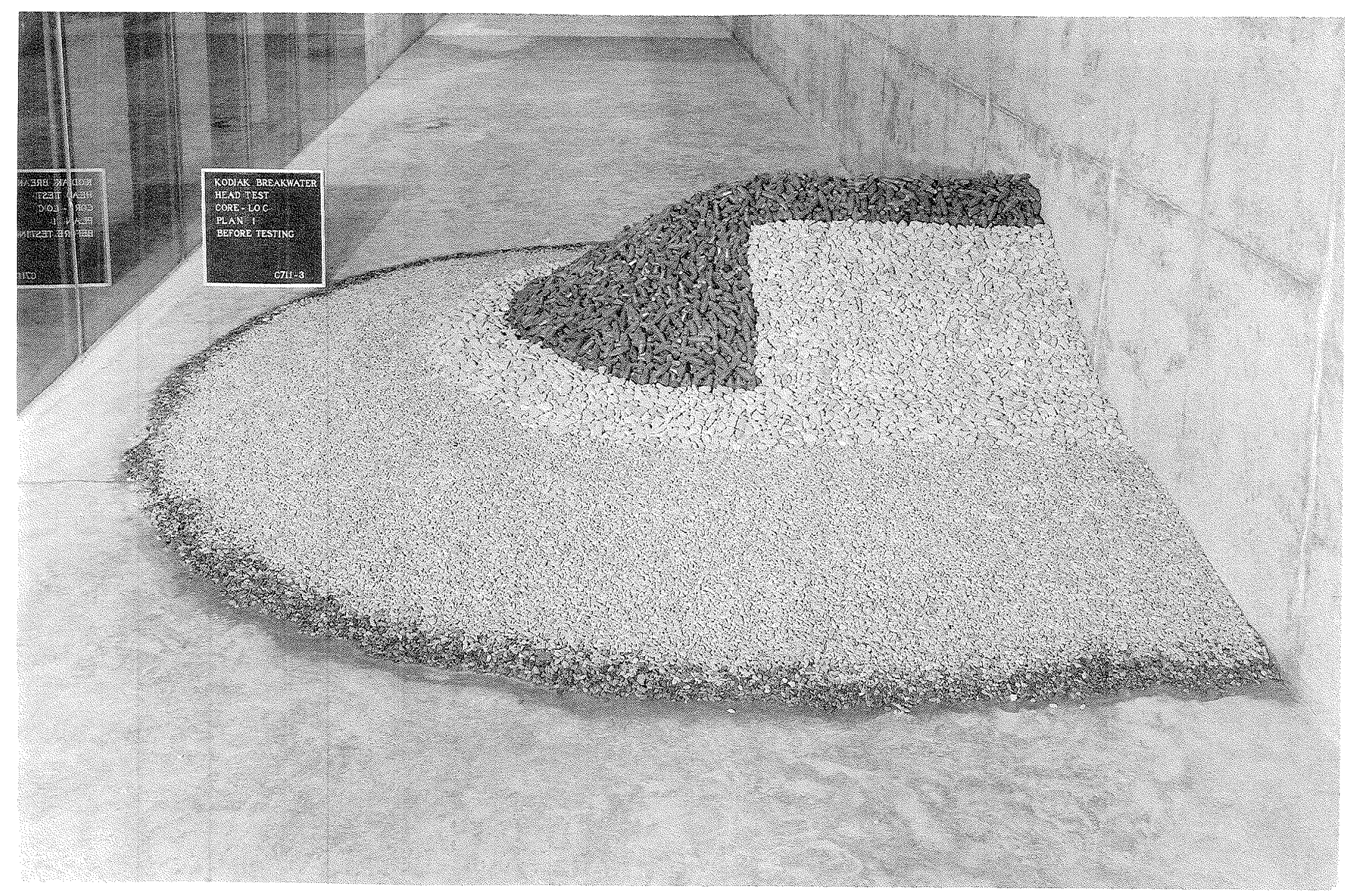

Photo 7. Harbor-side view of model breakwater Plan 1 before testing 




Photo 8. Sea-side view of model breakwater Plan 1 after testing 


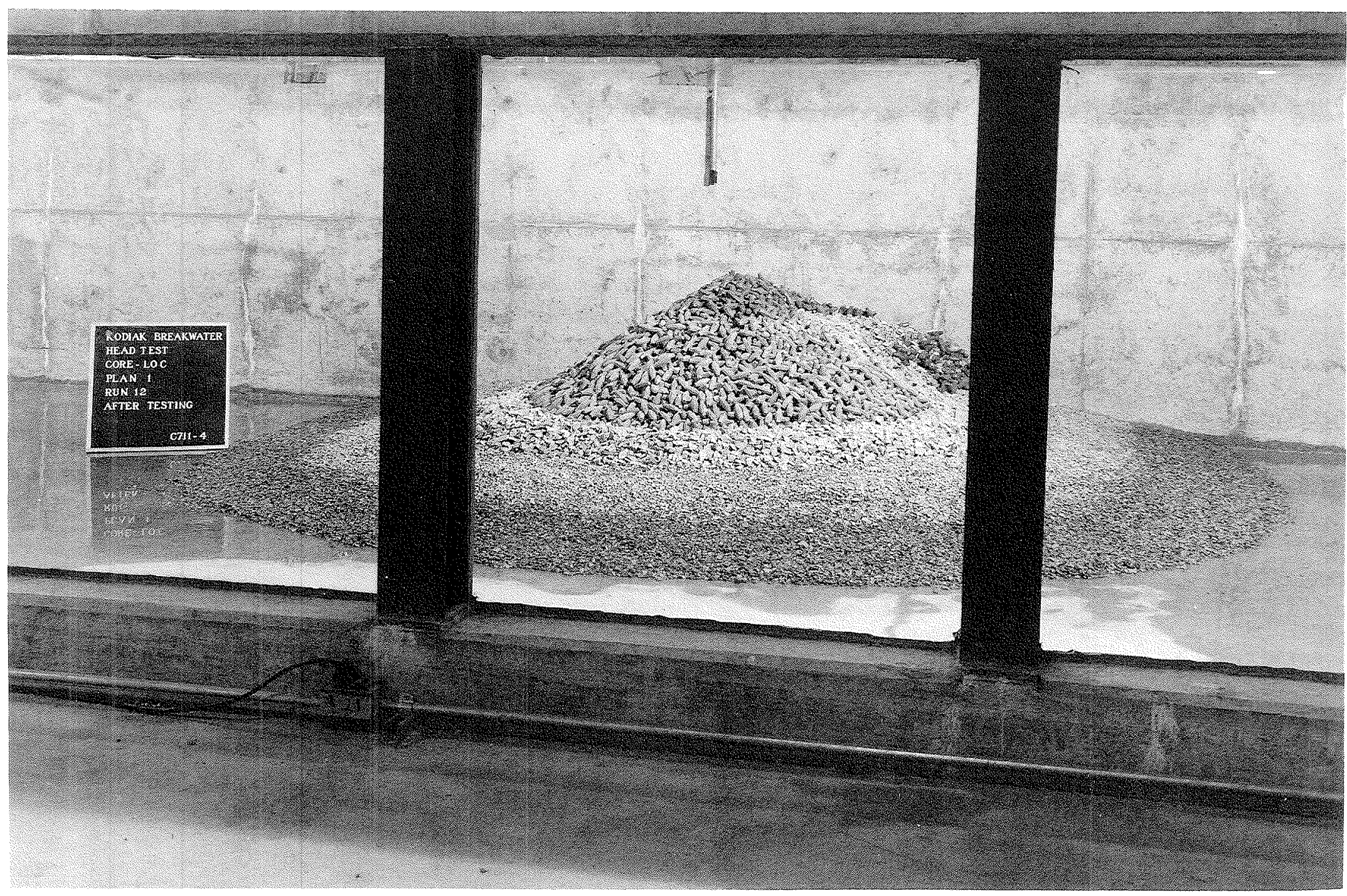

Photo 9. End view of model breakwater Plan 1 after testing 


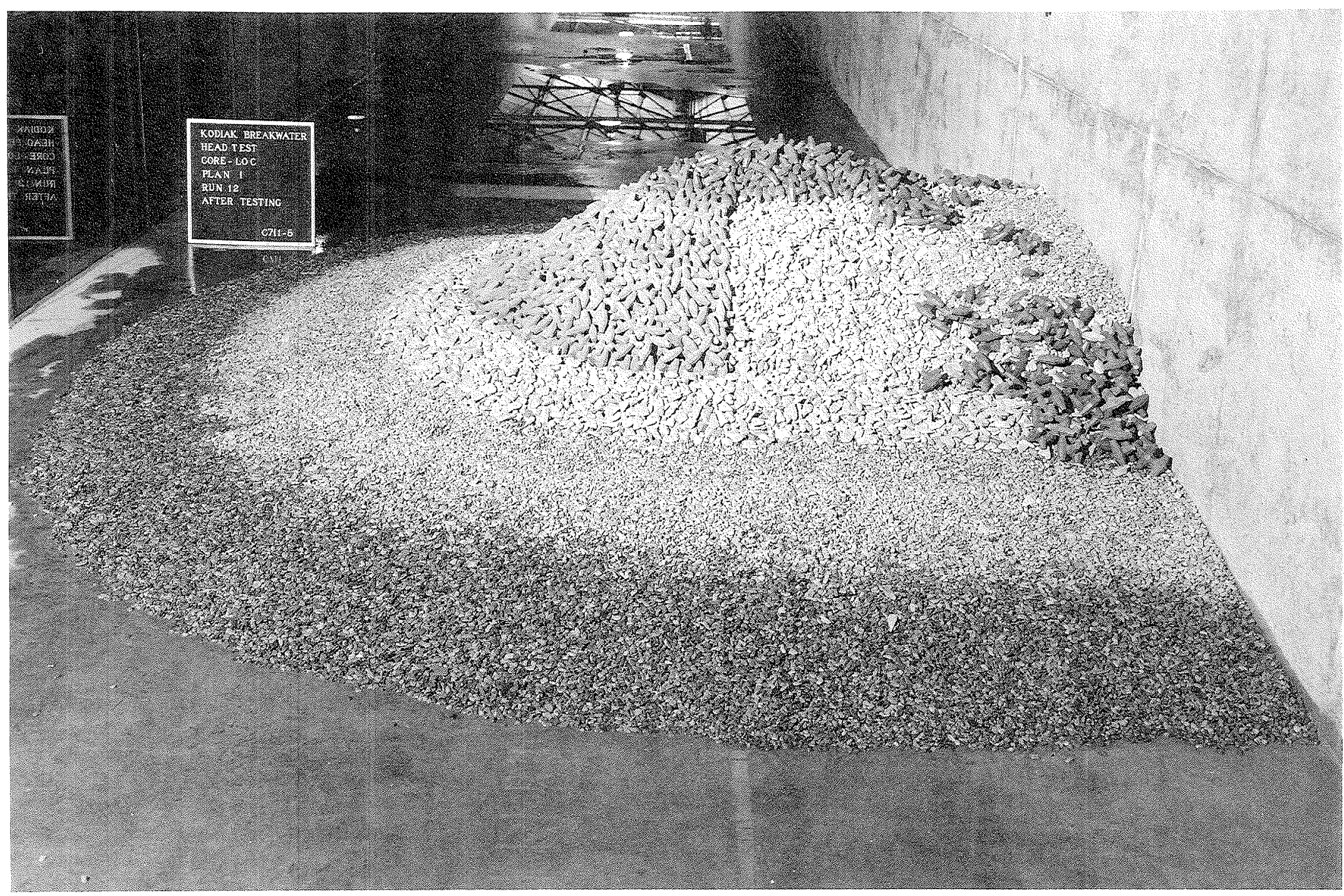

Photo 10. Harbor-side view of model breakwater Plan 1 after testing 


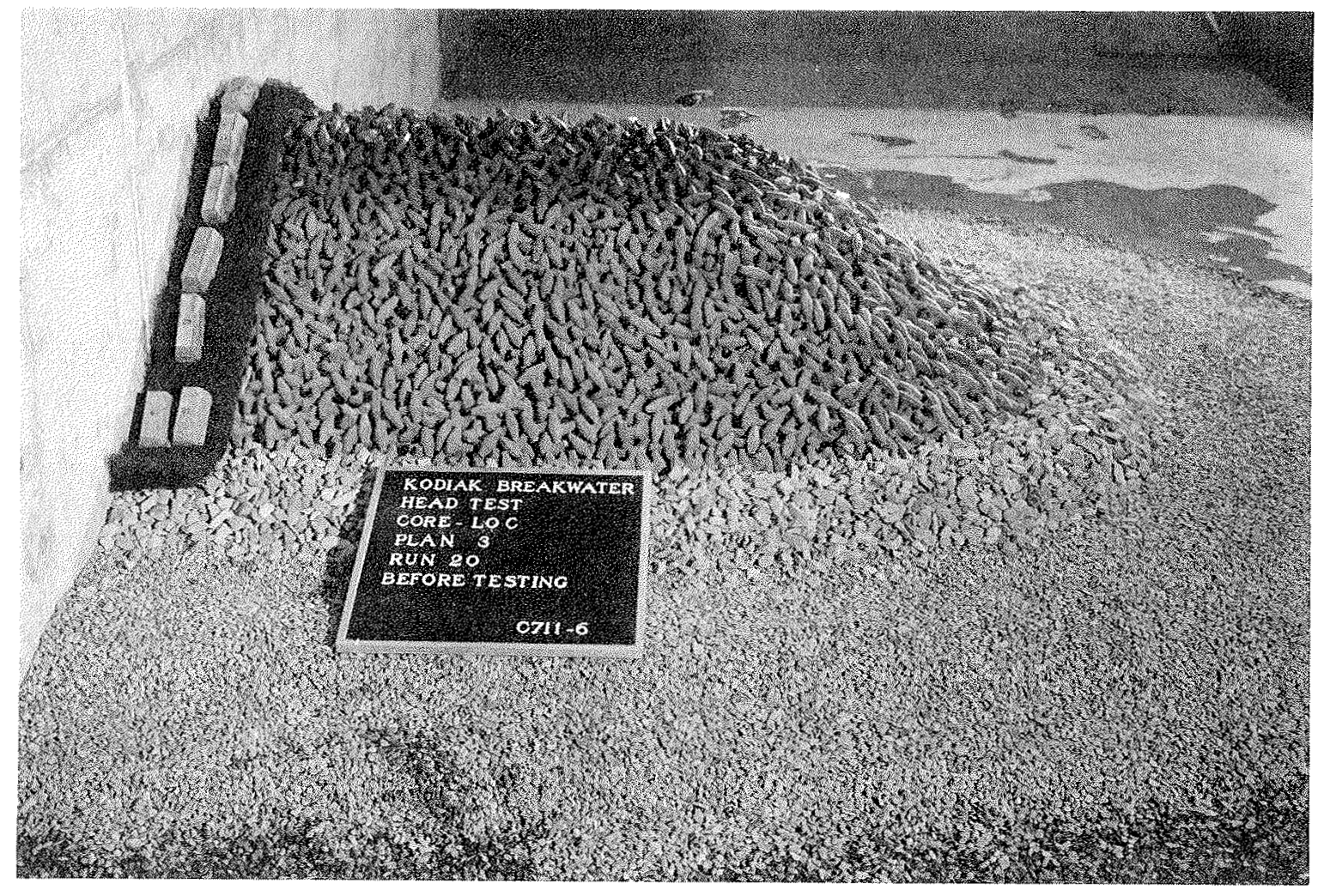

Photo 11. Sea-side view of model breakwater Plan 3 before testing

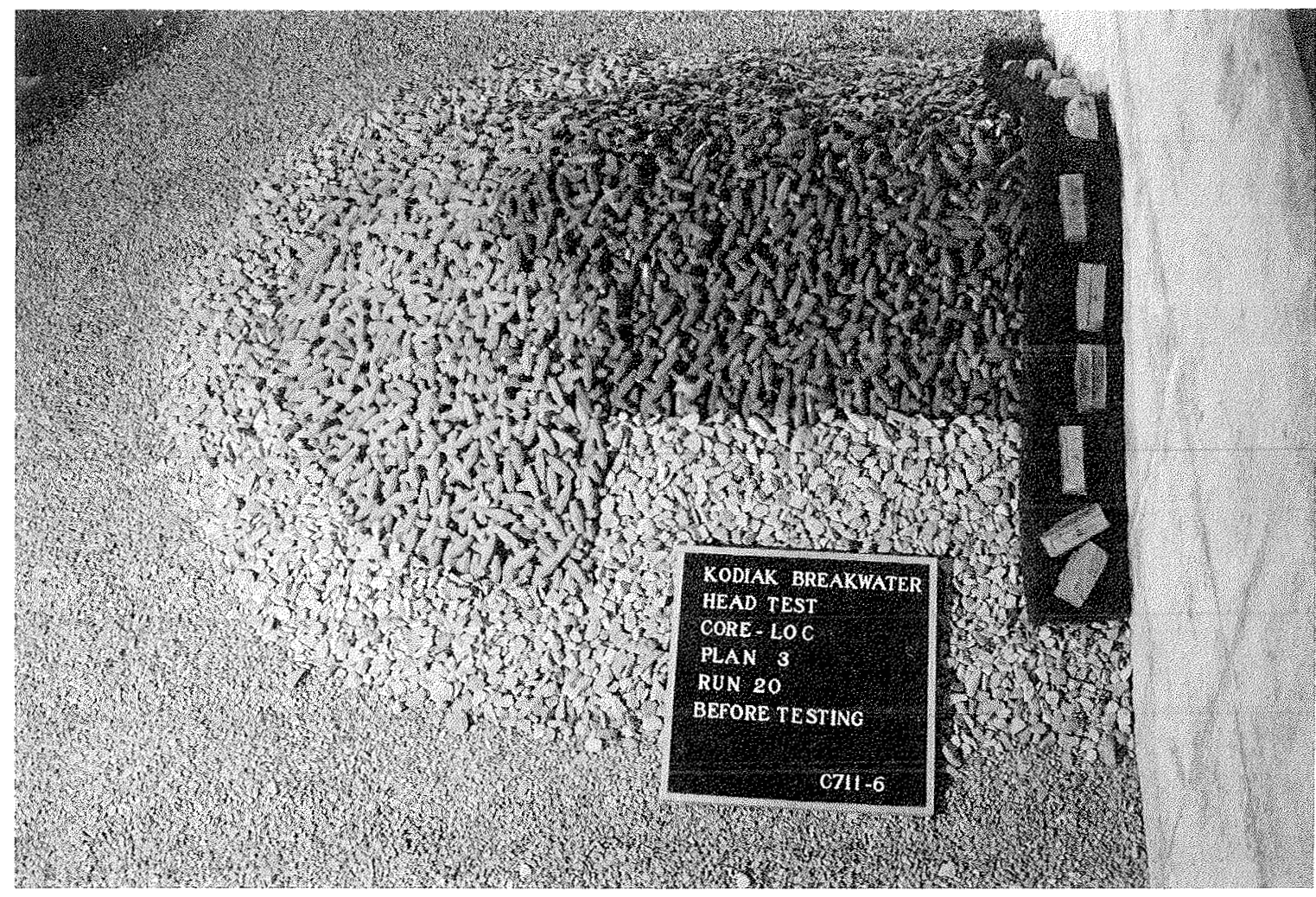

Photo 12. Harbor-side view of model breakwater Plan 3 before testing 


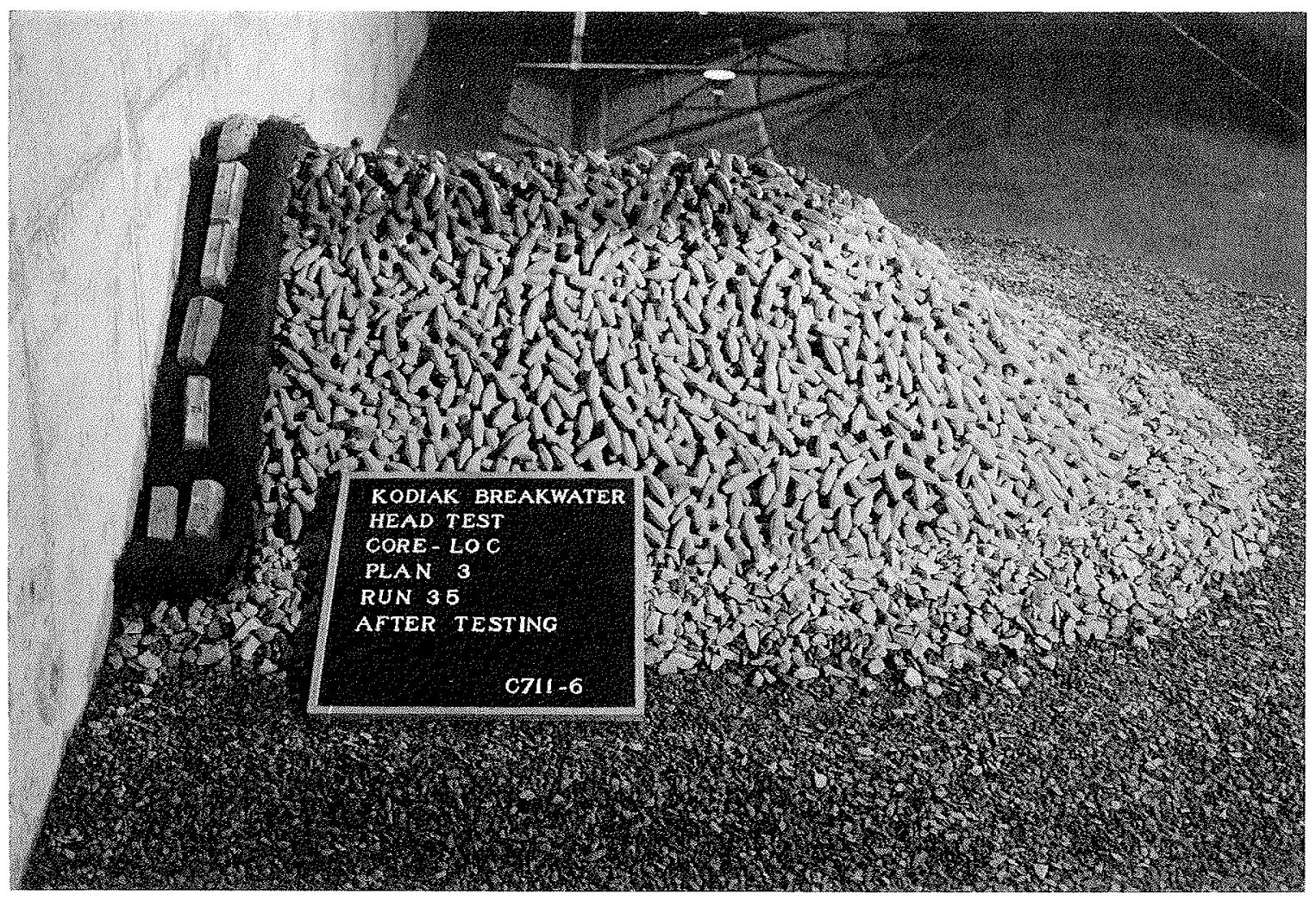

Photo 13. Sea-side view of model breakwater Plan 3 after testing

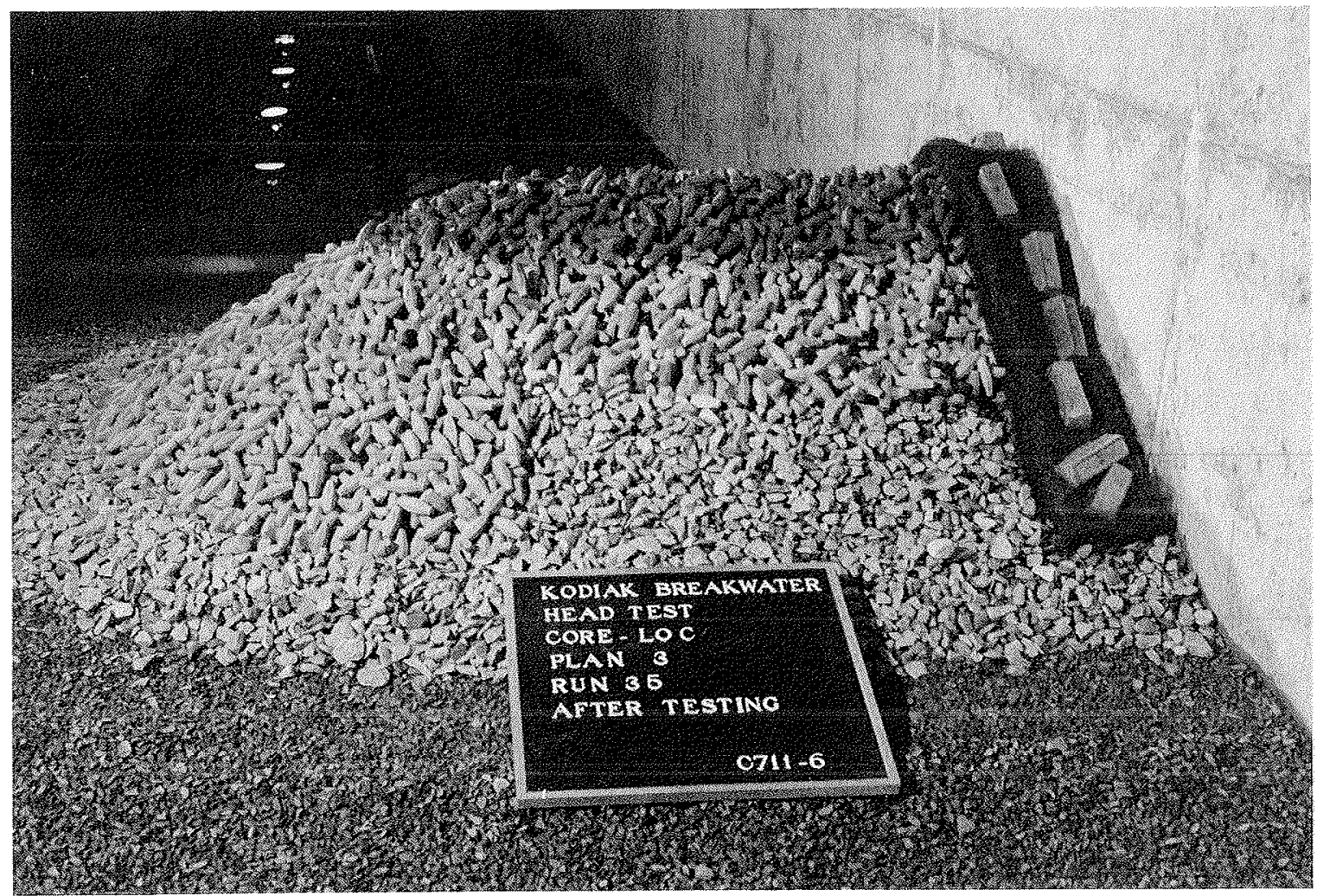

Photo 14. Harbor-side view of model breakwater Plan 3 after testing 


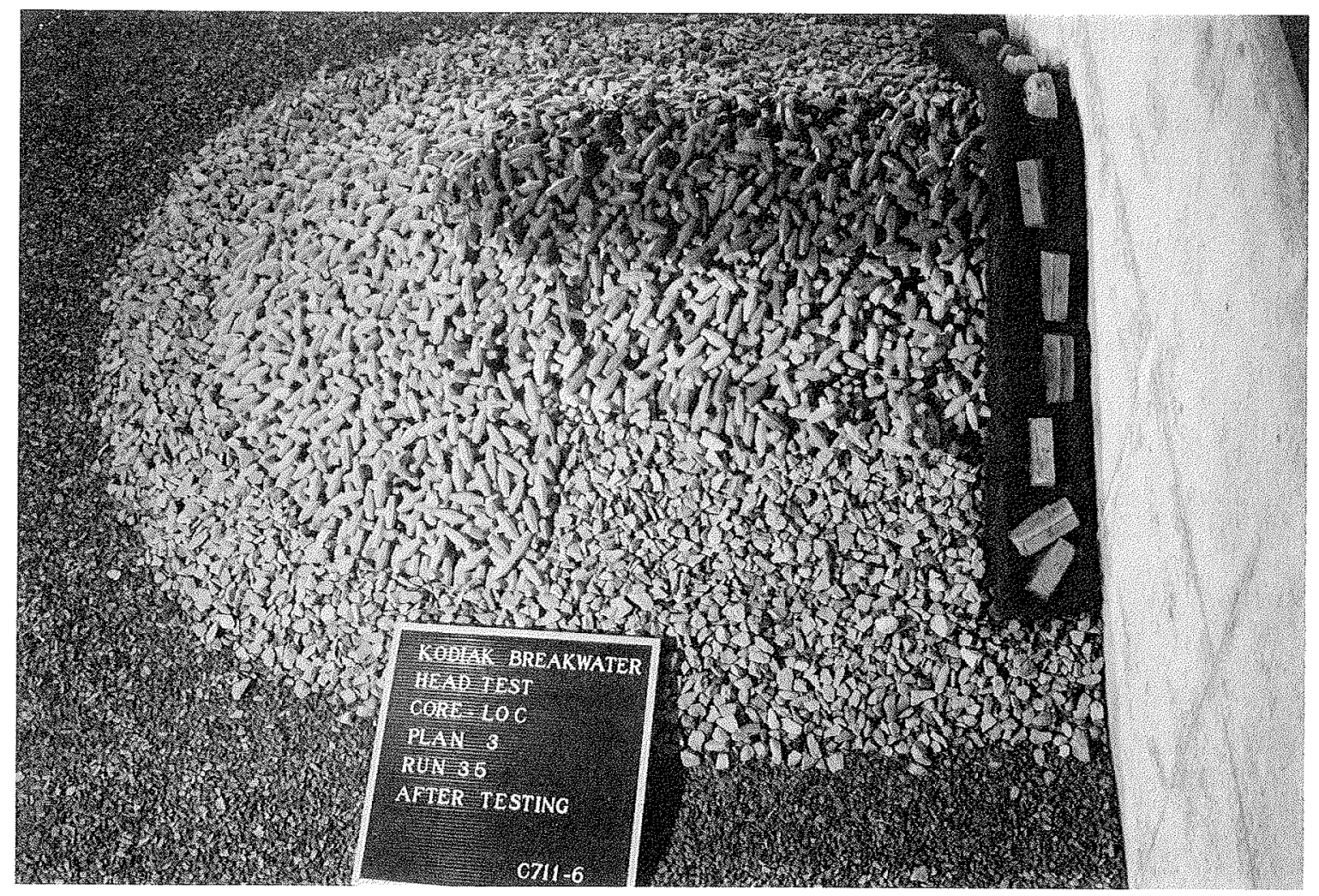

Photo 15. Damage sustained by model breakwater during testing of Plan 3

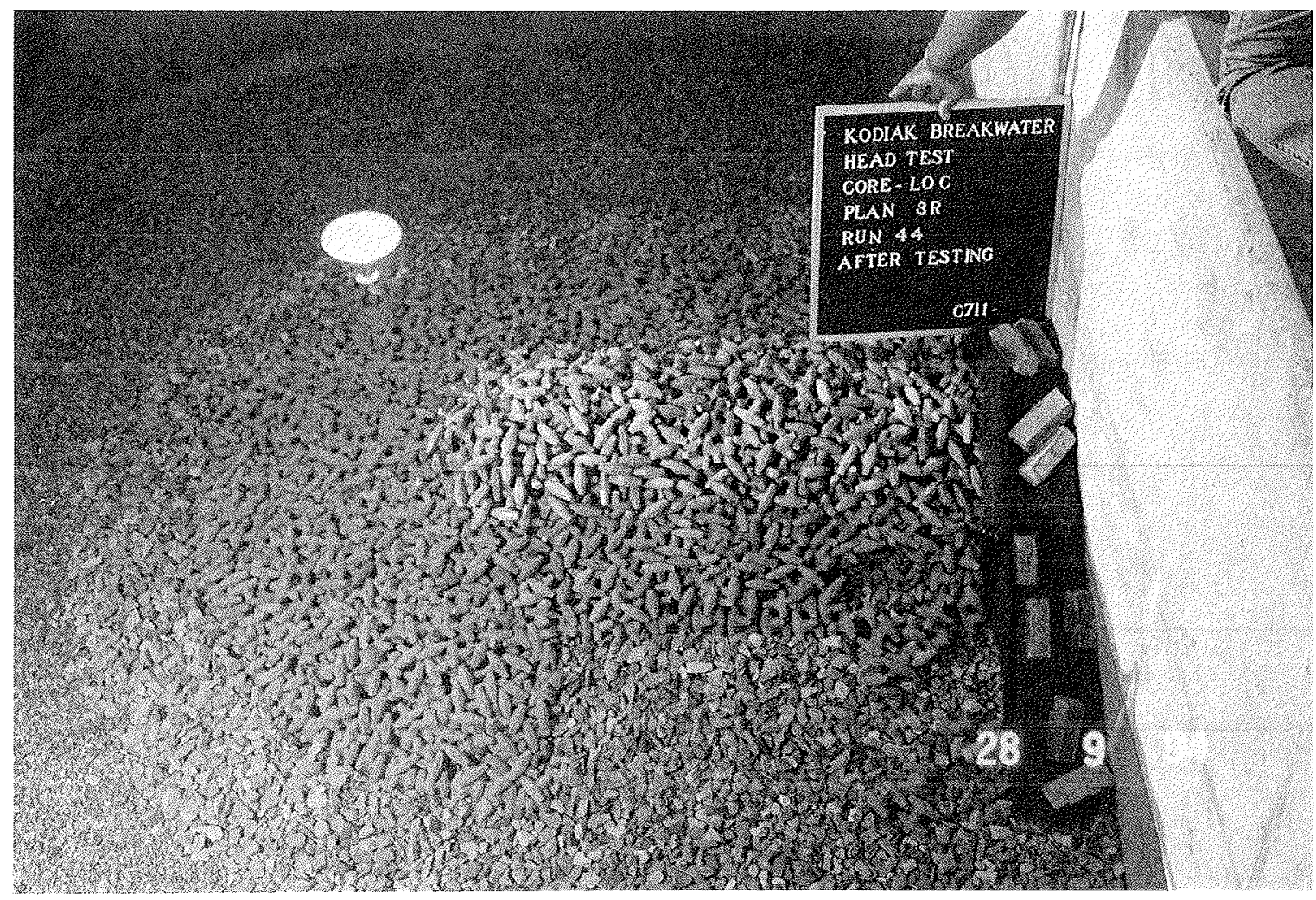

Photo 16. Damage sustained by model breakwater during demonstration runs of Plan 3R 


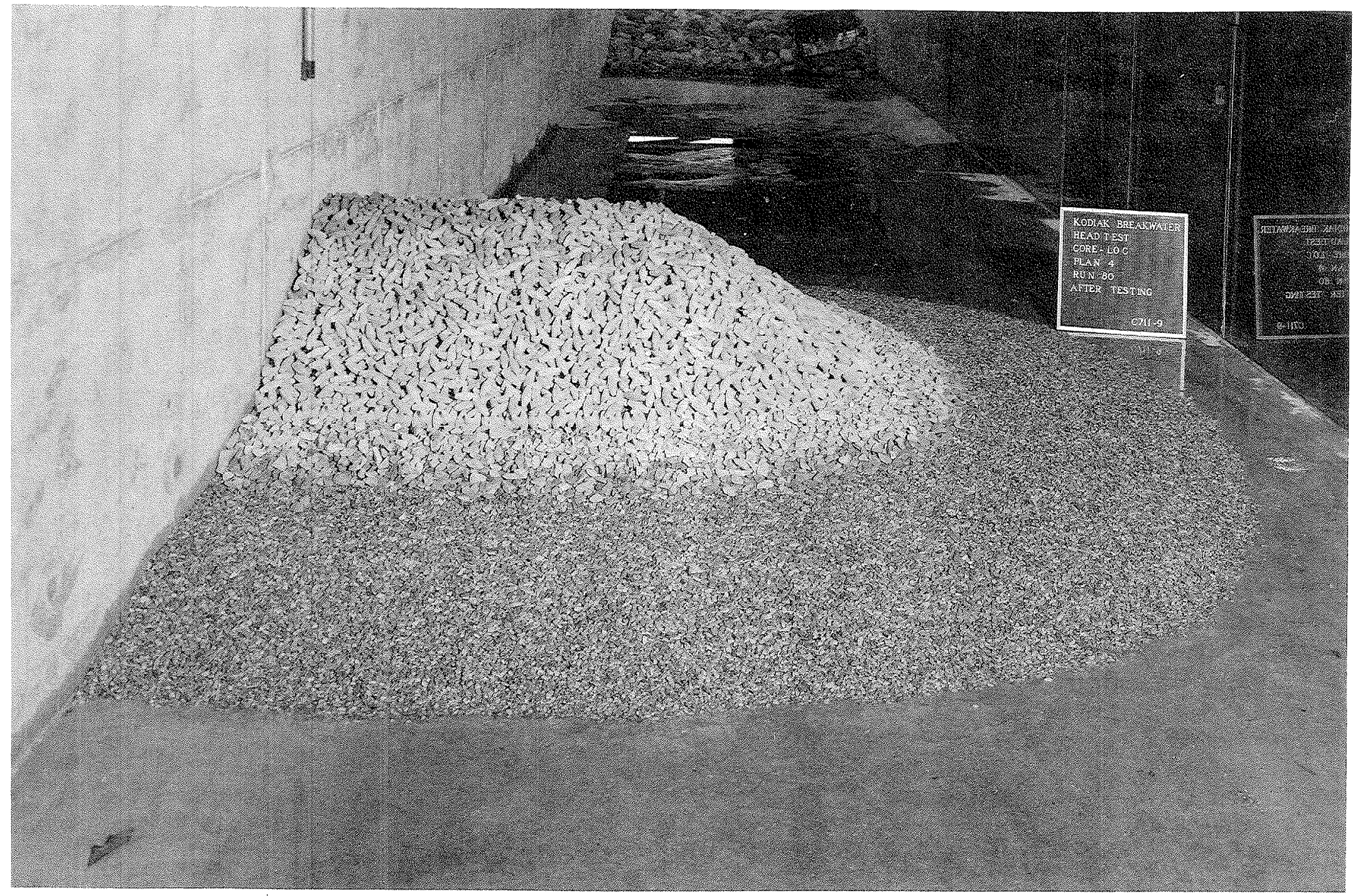

Photo 17. Sea-side view of model breakwater Plan 4 after testing 


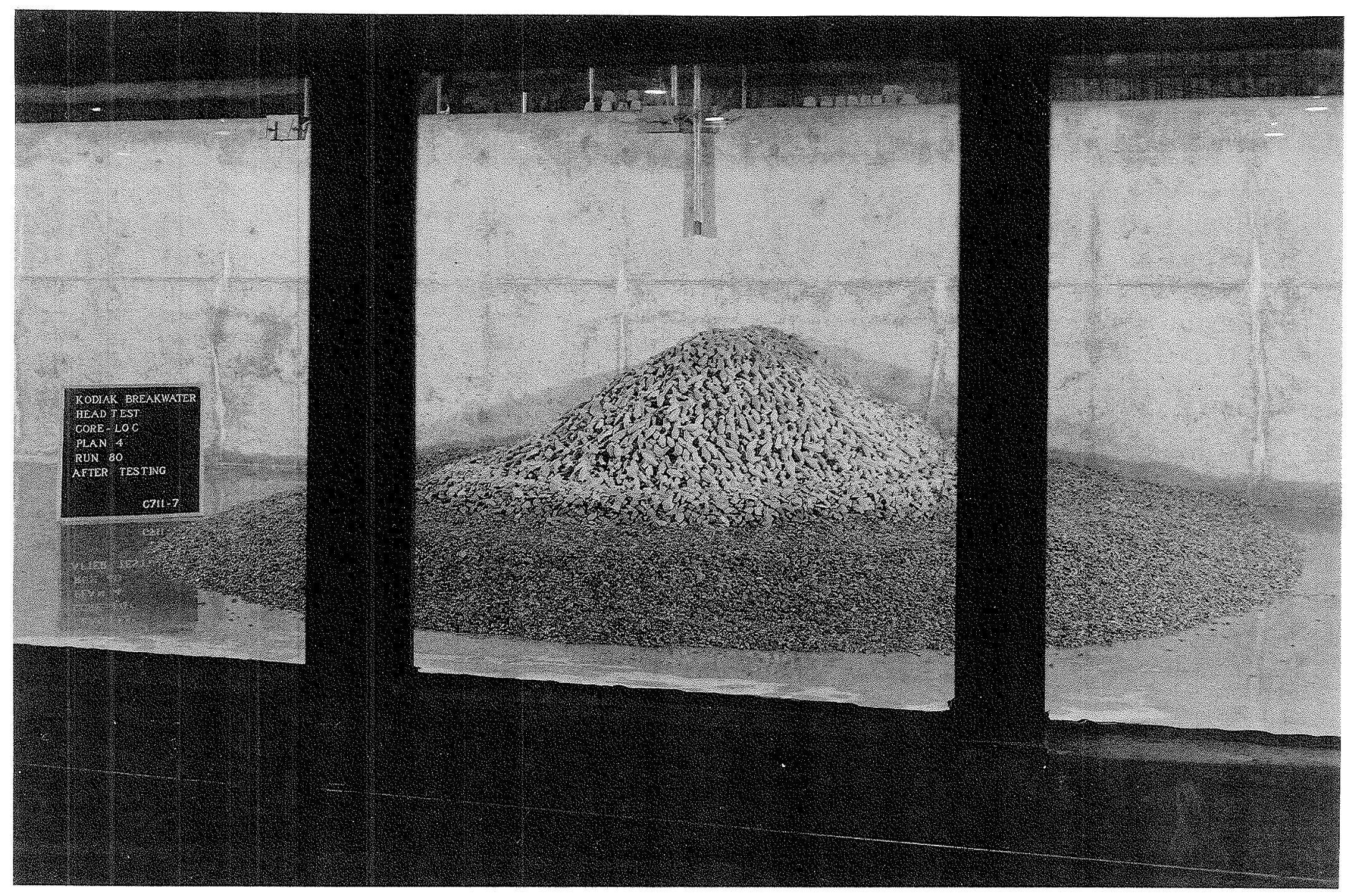

Photo 18. End view of model breakwater Plan 4 after testing 


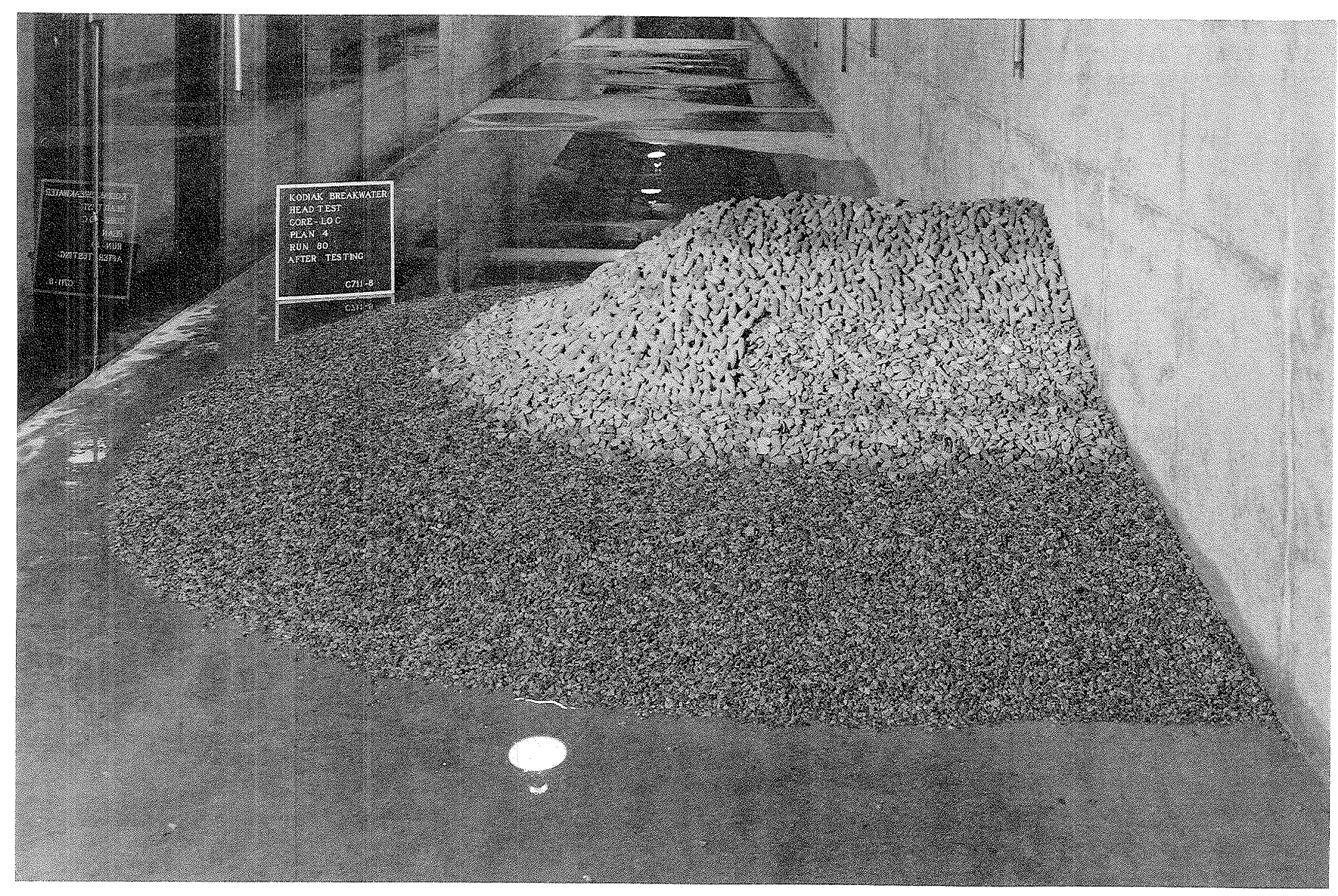

Photo 19. Harbor-side view of model breakwater Plan 4 after testing 




Photo 20. Sea-side view of model breakwater Plan 5 before testing 


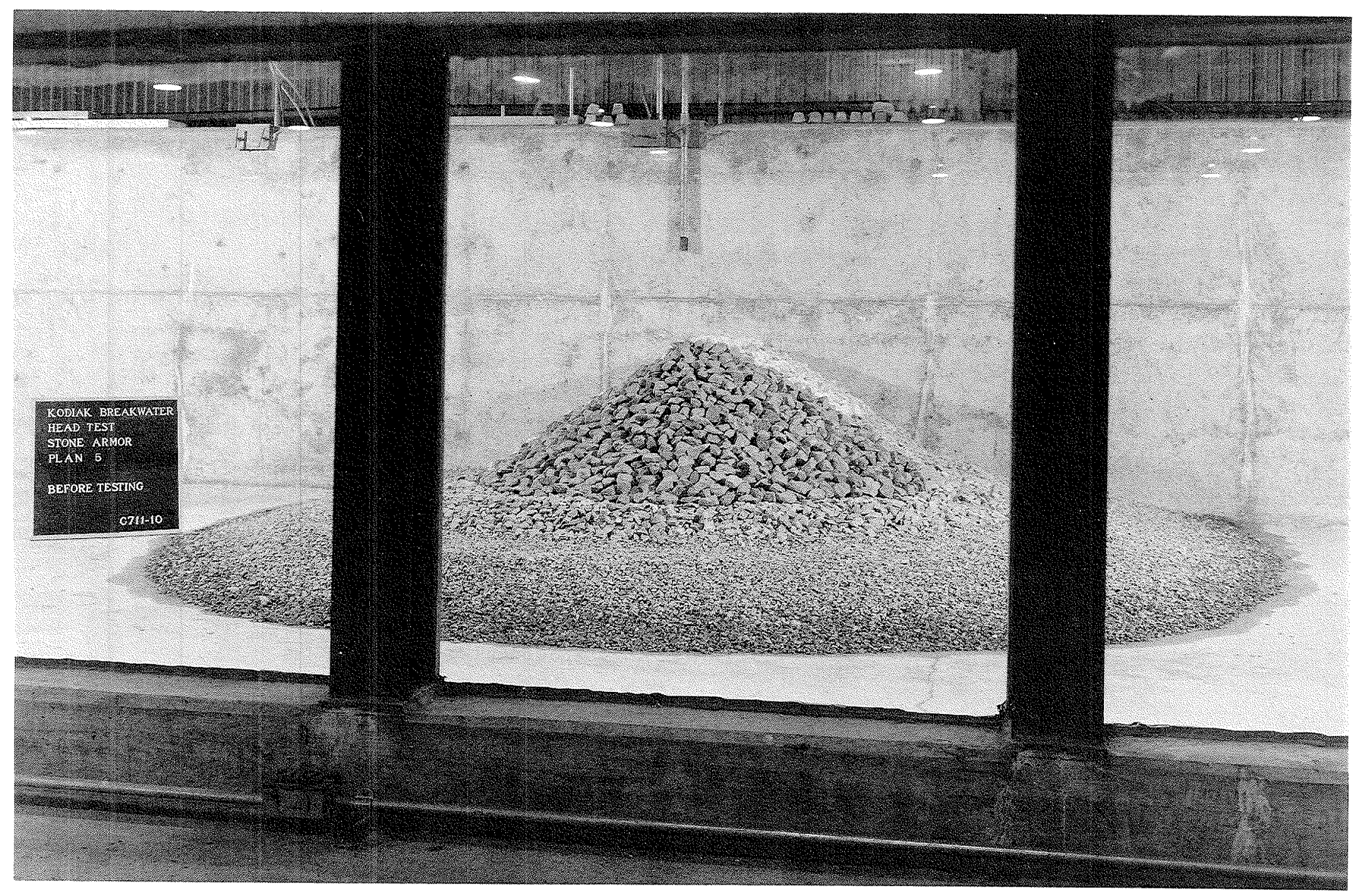

Photo 21. End view of model breakwater Plan 5 before testing 


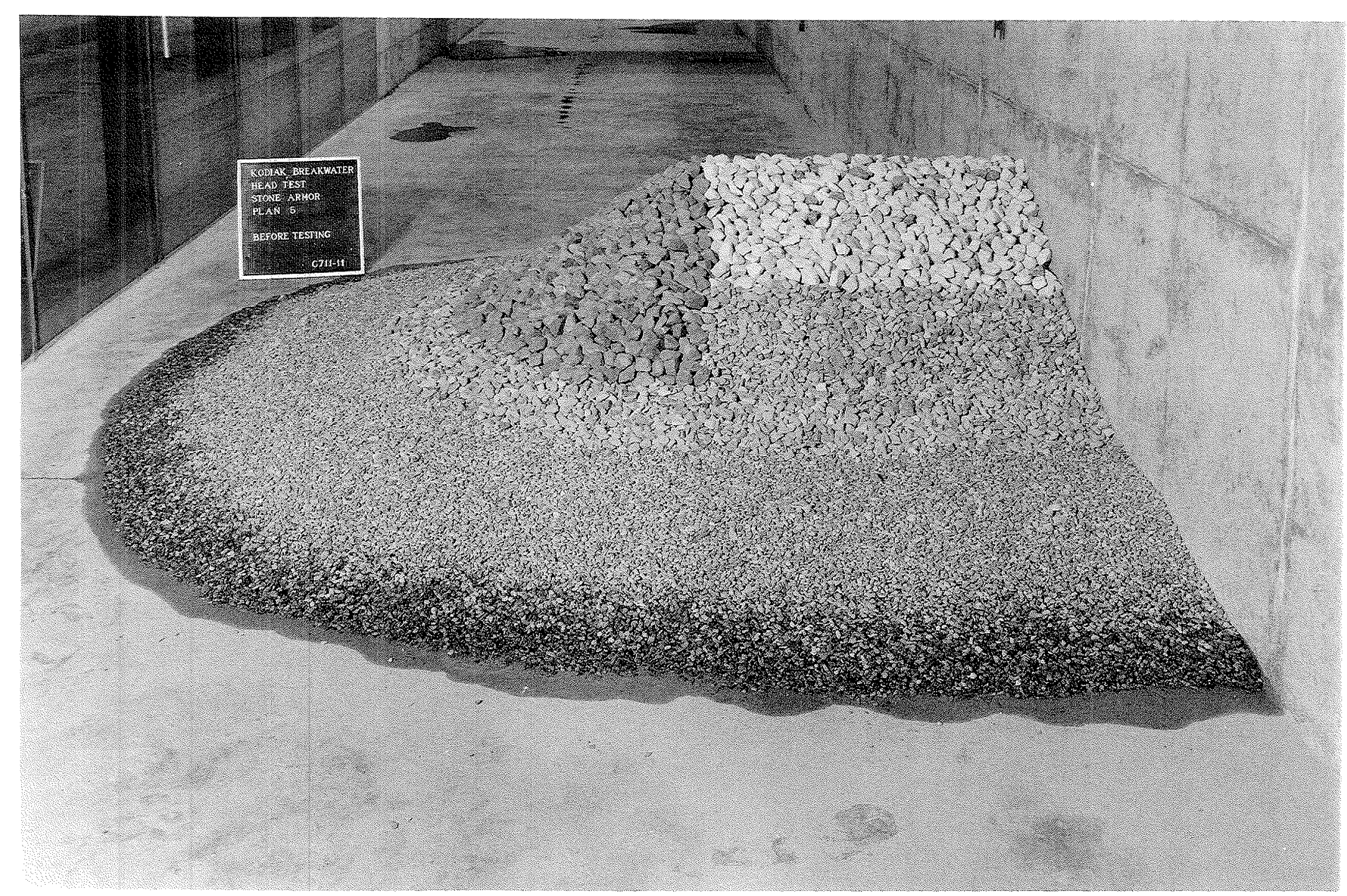

Photo 22. Harbor-side view of model breakwater Plan 5 before testing 


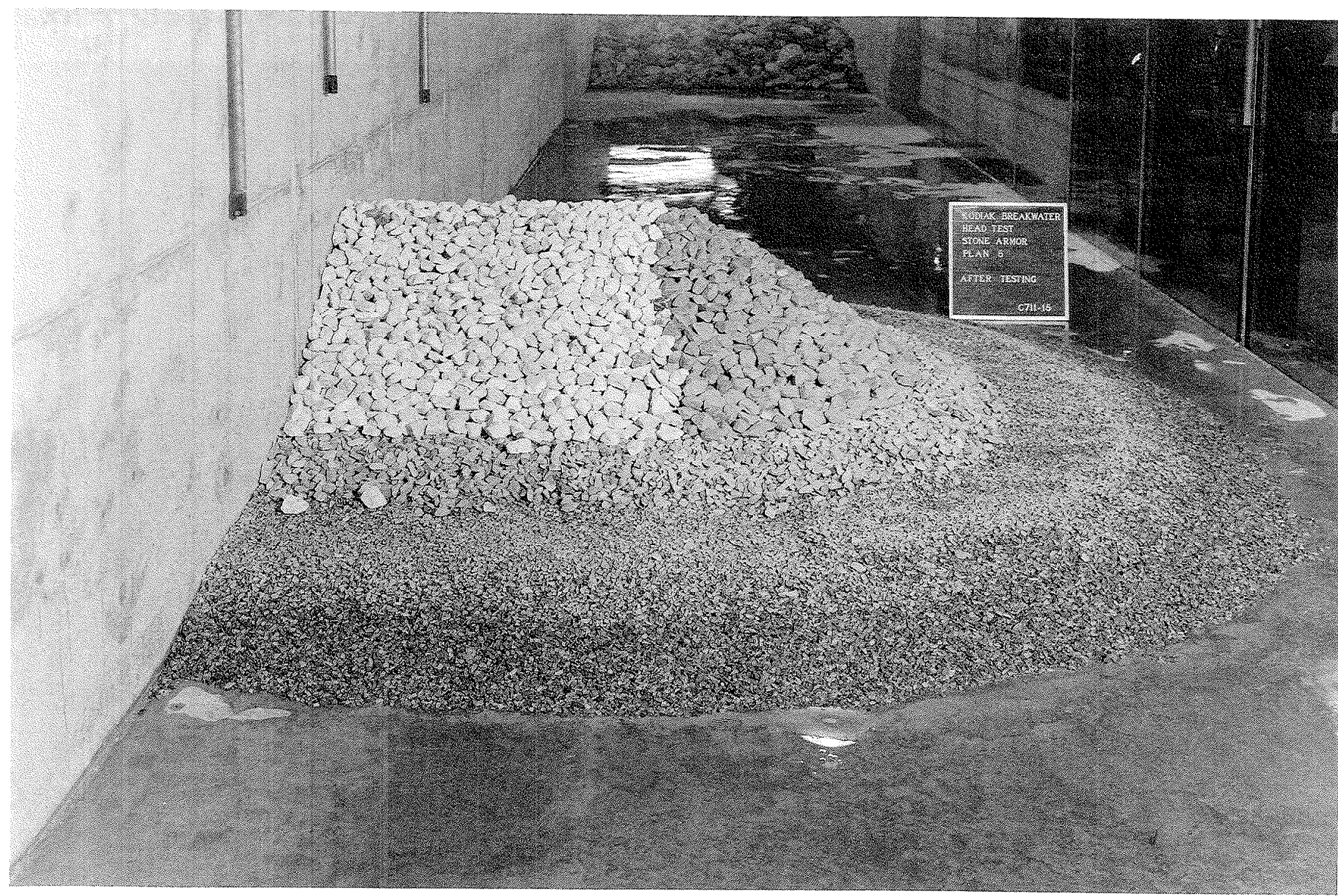

Photo 23. Sea-side view of model breakwater Plan 5 after testing 


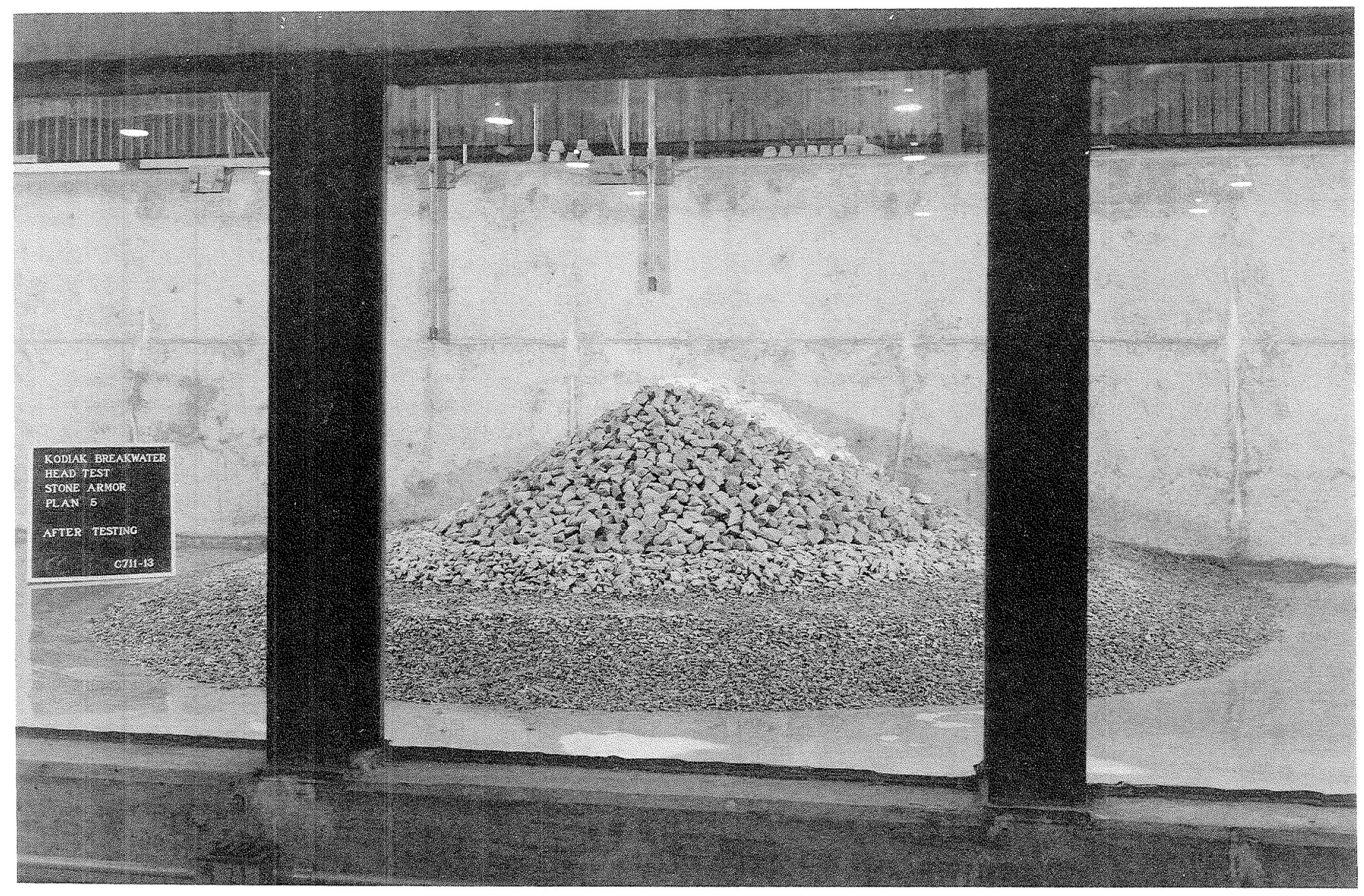

Photo 24. End view of model breakwater Plan 5 after testing 


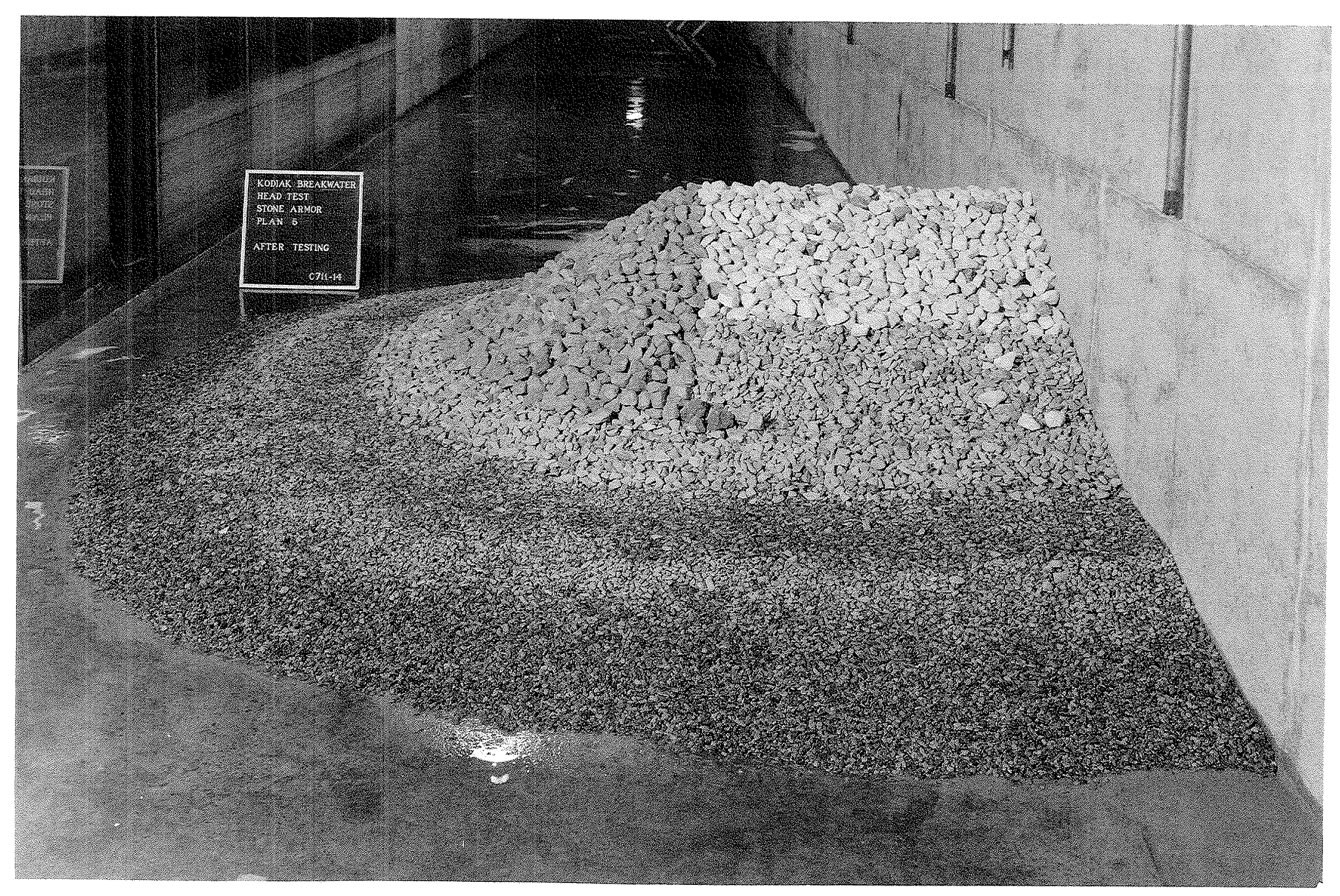

Photo 25. Harbor-side view of model breakwater Plan 5 after testing 


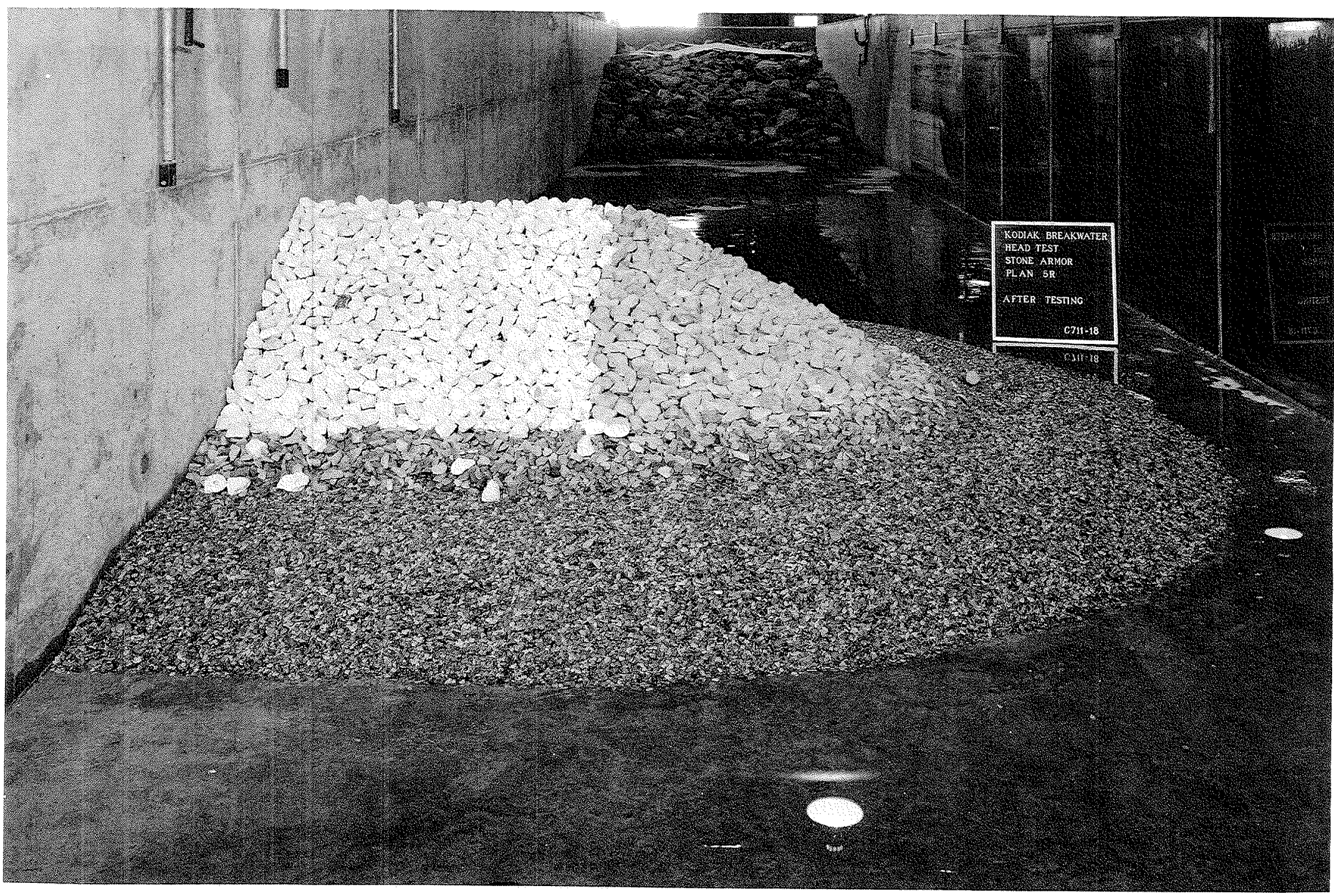

Photo 26. Sea-side view of model breakwater Plan 5R after testing 


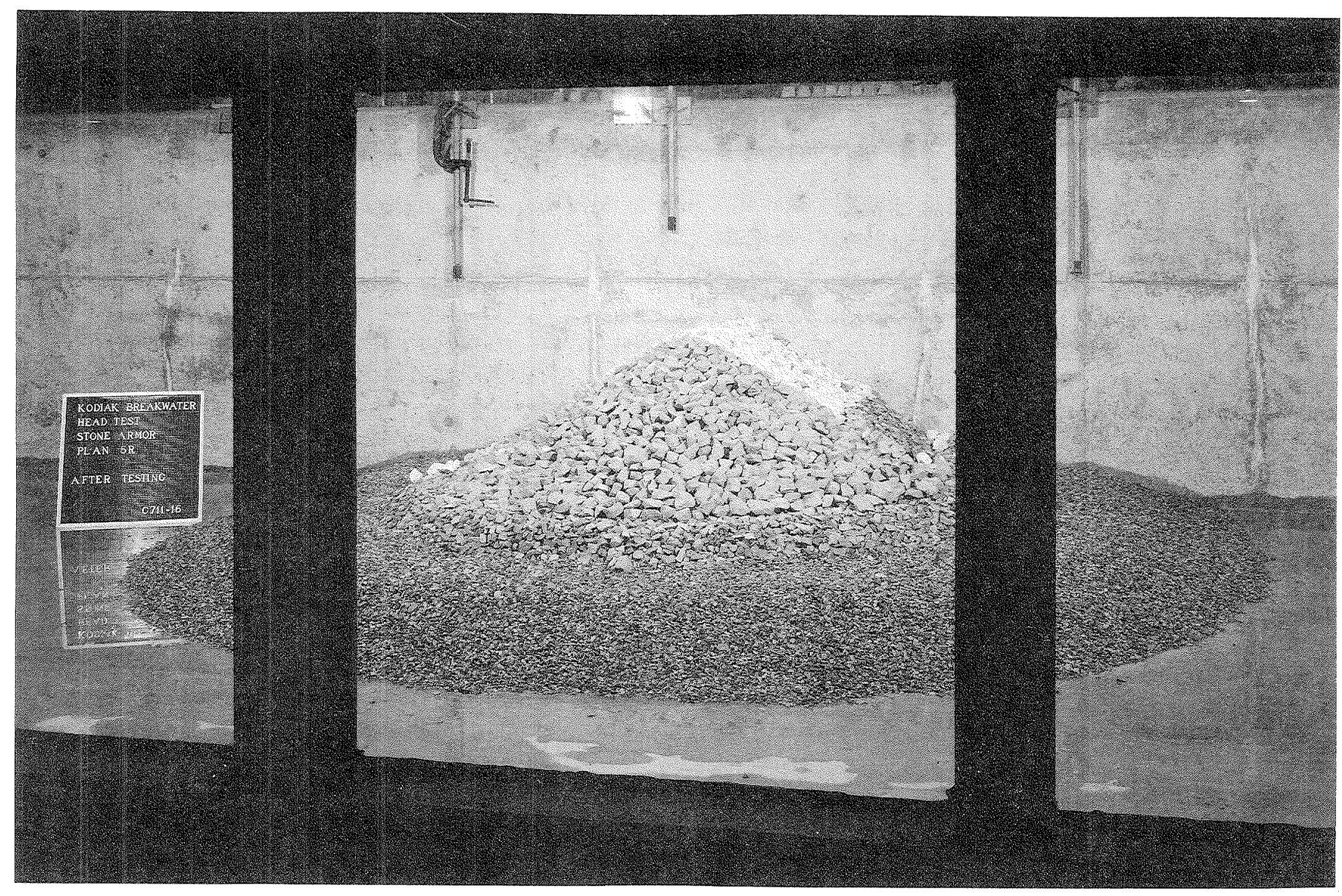

Photo 27. End view of model breakwater Plan $5 R$ after testing 


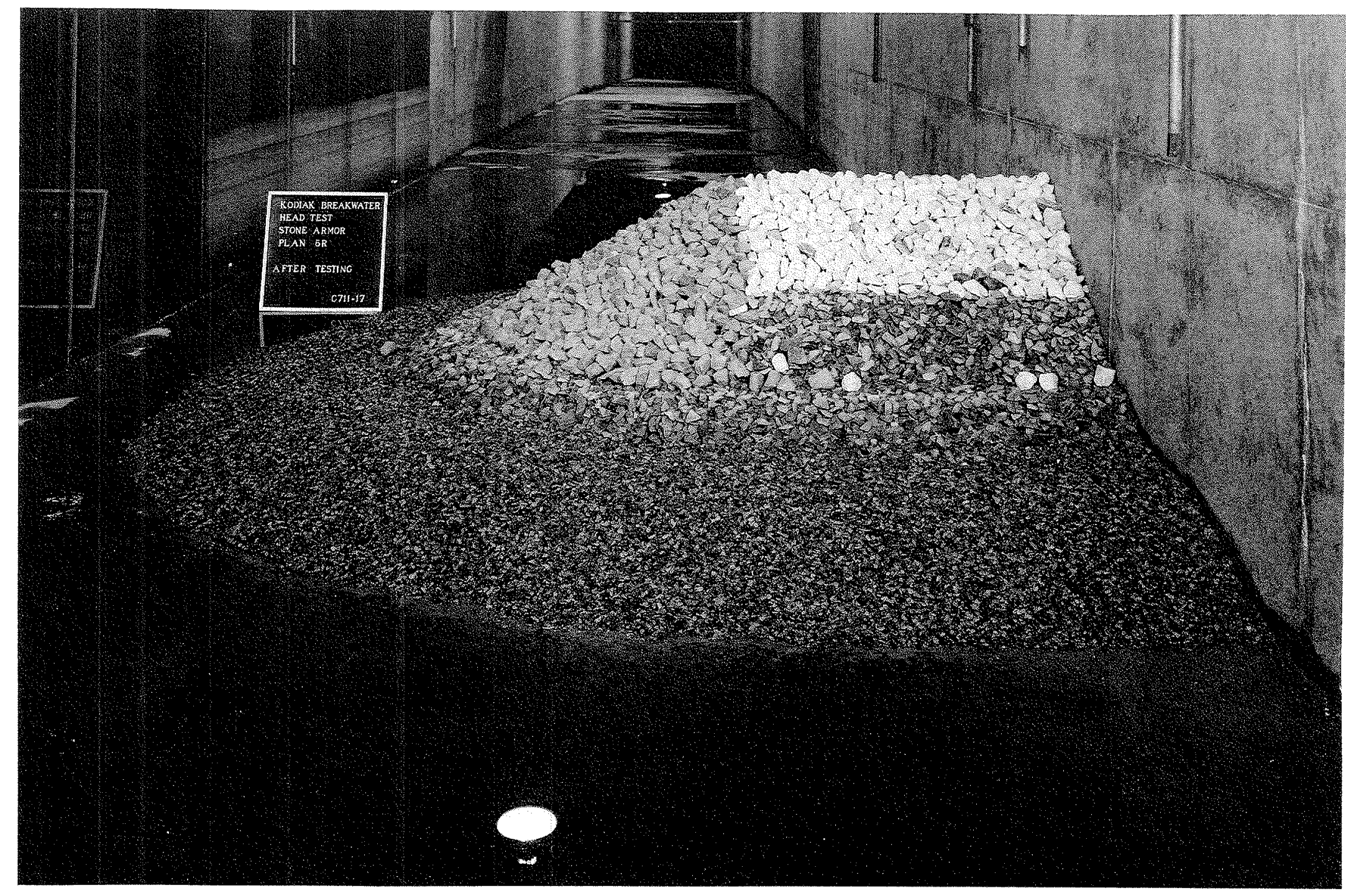

Photo 28. Harbor-side view of model breakwater Plan $5 \mathrm{R}$ after testing 


\section{Appendix A Notation}

$H_{n+0} \quad$ Zeroth moment wave height

$L \quad$ Length scale

$m \quad$ Subscript referring to model value

$p \quad$ Subscript referring to prototype value

$S_{a} \quad$ Relative specific gravity of armor unit

T Time scale

$T_{p} \quad$ Wave period of peak energy density

$W_{a} \quad$ Weight of individual stone or armor unit

$\gamma_{a} \quad$ Specific weight of armor unit

$\gamma_{w} \quad$ Specific weight of water 
Public reporting burden for this collection of information is estimaied to average 1 hour per response, including the ime for reviewing instructions, searching existing data sources, gathering and maintaining

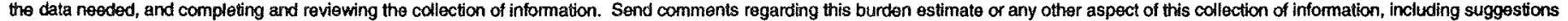
for reducing this burden, to Washington Headouarters Senvices, Directorate for Information Operations and Reports, 1215 Jefferson Davis Highway, Sutite 1204, Artington, VA22202-4302, and to the Office of Management and Budget, Paperwork Reduction Project (0704-0188), Washington, DC20503.

\begin{tabular}{|l|l|l}
\hline 1. AGENCY USE ONLY (Leave blank) & $\begin{array}{l}\text { 2. } \begin{array}{l}\text { REPORT DATE } \\
\text { May } 1996\end{array} \\
\text { 3. }\end{array}$ & $\begin{array}{l}\text { REPORT TYPE AND DATES COVERED } \\
\text { Final report }\end{array}$
\end{tabular}

\section{TITLE AND SUBTITLE \\ 5. FUNDING NUMBERS}

Physical Model Study of Breakwater Stability, Kodiak, Alaska

6. AUTHOR(S)

Donald L. Ward, Willie G. Dubose

7. PERFORMING ORGANIZATION NAME(S) AND ADDRESS(ES)

U.S. Army Engineer Waterways Experiment Station

3909 Halls Ferry Road, Vicksburg, MS 39180-6199

8. PERFORMING ORGANIZATION REPORT NUMBER

Miscellaneous Paper CERC-96-3

9. SPONSORINGMONITORING AGENCY NAME(S) AND ADDRESS(ES)

U.S. Army Engineer District, Alaska

P.O. Box 898

Anchorage, AK 99506-0898

11. SUPPLEMENTARY NOTES

Available from National Technical Information Service, 5285 Port Royal Road, Springfield, VA 22161.

12a. DISTRIBUTION/AVALLABILITY STATEMENT

Approved for public release; distribution is unlimited. 12b. DISTRIBUTION CODE

10. SPONSORINGMONTORING AGENCY REPORT NUMBER

\section{ABSTRACT (Maximum 200 words)}

This report presents results of a physical model study of the stability of a proposed main breakwater at Kodiak, AK. Model testing was conducted at the U.S. Army Engineer Waterways Experiment Station (WES) during the period June to November 1994. A preliminary design and economic study indicated that the cost of breakwater construction could be reduced by $\$ 1.2$ million by armoring the main breakwater with Core-Loc concrete armor units, recently developed at WES's Coastal Engineering Research Center. Although the Core-Loc armor units have performed well in laboratory tests, Core-Locs had not been tested on a prototype structure and had only minimal testing under three-dimensional conditions of a breakwater head. Testing of the proposed Core-Loc breakwater design was therefore imperative.

Test results showed that $1,350-\mathrm{kg}(3,000-\mathrm{lb})$ Core-Loc armor units provided stable armoring of the proposed Kodiak breakwater on both the head and trunk when placed in the configuration designated as Plan 4 in this test series and subjected to the wave environment replicated in these tests.

The model was also tested using armor stone with $W_{50}=1,450 \mathrm{~kg}(3,200 \mathrm{lb})$. Minor scour holes developed on the model during tests with armor stone, but did not threaten the structural integrity of the breakwater. The armor stone was shown to satisfactorily protect the breakwater when subjected to the wave environment replicated in these tests.

14. SUBJECT TERMS

Armor stone

Breakwater stability
Core-Loc armor units

Kodiak, AK
15. NUMBER OF PAGES 56

16. PRICE CODE
17. SECURITY CLASSIFICATION OF REPORT UNCLASSIFIED
18. SECURITY CLASSIFICATION OF THIS PAGE UNCLASSIFIED

NSN 7540-01-280-5500

Standard Form 298 (Rev. 2-89) Prescribed by ANSI Std. Z39-18 298-102
SECURITY CLASSIFICATION 20. LIMITATION OF ABSTRACT OF ABSTRACT 